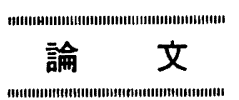

UDC $669.14 .018 .252 .3-158.81: 669.14 .018 .255-158.81: 536.421 .4: 620.186 .1$ 急冷凝固した工具に現われる相の観察*

新井透**.小松登**

\title{
Determination of Phases in Tool Steels Quenched from Liquid State
}

Tohru ARAI and Noboru Komatsu

\section{Synopsis :}

Extensive studies are being carried out with high speed steel made from atomized powders, mainly for the establishment of mass production technique and the investigation of various properties of such steels. Almost no literature has been published on the metallographic study of the steels rapidly quenched from liquid state. Therefore, the solidification process during quenching of tool steels from liquid state was studied in this work.

Microscopic observation, X-ray diffraction and electron probe microanalysis were performed on the atomized powders, thin plates by splat cooling, and beads made by several methods such as electron beam and transfer-plasma melting. The materials studied included high speed steels, cold work die steels and hot work die steels.

The results are summarized as follows.

(1) When high speed steels and die steels were quenched from liquid state, carbides were crystallized in the form of extremely fine particle or plate.

(2) Quenched from liquid state, high speed steels were crystallized in the following steps.

Primary $\gamma, \gamma+$ cabide eutectic

Sometimes $\delta$-ferrite was crystallized as primary phases and remained even at the room temperature.

(3) Hot work die steel was crystallized in the same process as high speed steels but no $\delta$-ferrite was found.

(4) Carbides crystallized in SKH9,SKH54 high speed steels and SKD61 hot work die steels were not $\mathrm{M}_{6} \mathrm{C}+\mathrm{MC}$ type but $\mathrm{M}_{2} \mathrm{C}+\mathrm{MC}$ type.

(Received June 28, 1971)

\section{1. 緒言}

工具鋼の組織を改善し，切削性能を向上せしめる一つ の手段として，粉末治金で工具鋼あるいは工具用合金を 製作することが注目され，高速度鋼の噴霧粉を熱間静水 圧仕縮する方法1)2), 高速度鋼やステライトの噴霧粉を キャンニング押出する方法3)，同じく粉末压延する方 法5) 高速度鋼貨霧粉を焼結鍛造する方法6)などが世界各 国で研究され，一部は近く実用化の気運にある。このよ うに粉末治金法が 研究対象として興味を持たれる理由 は，これらの方法によつて作られた工具鋼が微細で均一 に分布した炭化物を持ち, 工具鋼としての諸性質がすぐ れていると期待されるからであつて，すでに鍛造材や鋳 造材の工其鋼に比べて切削性能や靶性がすぐれていると のデータがしばしば報告されている1)ー6). このように組 織ひいては工具鋼としての諸性質が改善されるのは，イ
ンゴットや鋳造工具に比べて賲霧粉がきわめて大きな冷 却速度で凝固するためであるが，高合金工具鋼とくに高 速度鋼のように状態図的に複雑な凝固過程をたどる鋼 が，大きな冷却速度で凝固すれば単に晶出する炭化物が 微細であるばかりでなく，徐冷㠜固の場合とは凝固過程 が異なる可能性が大きいと考えられる，しかるにこれま での研究では炭化物が微細であることのみが報ぜられ， 急冷凝固の観点から組成を論じた報告は見られない。し たがつてわれわれは急冷凝固工具鋼に関する研究の第一 段階としてまず工具鋼の急冷凝固組織を観察した。

本研究では急冷凝固工具龬として噴霧粉のほかにスプ ラットクーリング材（以下スプラットと称す）およびわ れわれが局部急冷㠜固処理材と呼ぶものを用いた．局部

* 昭和 45 年 4 月, 10 月本会講演大会にて発表 昭和 46 年 6 月 28 日受讨

**（株）豊田中央研究所工博 
Table 1. Chemical composition of SKH 9 atomized powders (\%).

\begin{tabular}{|c|c|c|c|c|c|c|c|c|c|c|c|c|}
\hline & & C & $\mathrm{Si}$ & $\mathrm{Mn}$ & $\mathbf{P}$ & $\mathrm{S}$ & W & Mo & $\mathrm{Cr}$ & $\mathrm{V}$ & $\mathrm{O}$ & $\mathrm{N}$ \\
\hline Forged bar & & $0 \cdot 83$ & $0 \cdot 24$ & 0.33 & 0.019 & 0.005 & $6 \cdot 17$ & $5 \cdot 18$ & $4 \cdot 06$ & $1 \cdot 86$ & 0.017 & 0.042 \\
\hline Atomized powder & $\mathrm{r} \begin{array}{r}\text { mesh } \\
20 \sim 100\end{array}$ & $0 \cdot 81$ & $0 \cdot 30$ & $0 \cdot 26$ & $*$ & $*$ & $6 \cdot 04$ & $5 \cdot 10$ & $3 \cdot 98$ & $1 \cdot 81$ & $1 \cdot 79$ & 0.041 \\
\hline$"$ & $100 \sim 150$ & $*$ & $*$ & $*$ & $*$ & $*$ & $*$ & $*$ & $*$ & $*$ & $1 \cdot 32$ & $*$ \\
\hline " & -325 & $*$ & $*$ & $*$ & $*$ & $*$ & $6 \cdot 04$ & $5 \cdot 08$ & $4 \cdot 10$ & $1 \cdot 82$ & 0.62 & $*$ \\
\hline
\end{tabular}

* Not determined

Table 2. Carbon content in SKH 9 atomized powders reduced at $700^{\circ} \mathrm{C}$ in $\mathrm{H}_{2}$ atmosphere $(\%)$.

\begin{tabular}{c|l|l|l|l|l|l|l}
\hline Mesh & 20 & 100 & 150 & 200 & 250 & \multirow{2}{*}{ Lot No } \\
\hline 1 & $\sim 100$ & $\sim 150$ & $\sim 200$ & $\sim 250$ & $\sim 325$ & -325 \\
\hline 2 & 0.75 & 0.78 & 0.79 & 0.79 & 0.78 & 0.79 \\
& 0.74 & 0.74 & 0.77 & 0.76 & 0.76 & 0.77 \\
\hline
\end{tabular}

急冷凝固処理材とは工具鋼材を局部的に溶融した後急冷 凝固させたものであるが，急冷㠜固の手段としては特別 な冷却操作を用いるかわりに, 電子ビームやレーザのよ うな高エネルギー密度の熱源を用いた, 高エネルギー密 度の熱源を用いると，熱源を絶つだけで非溶融部への熱 伝導によつて溶融金属は大きな泠却速度で㠜固する.

高速度鋼, 冷間ダイス鋼, 熱間ダイス鋼およびW, $\mathrm{Mo}, \mathrm{Cr}, \mathrm{V}$ の 1 種または 2 ～ 3 種を含む高炭素鋼を対 象とした結果, 高速度鋼や熱間ダイス鋼は徐冷凝固の場 合と異なつた過程で凝固すること, 凝固条件によつて高 速度鋼には巨大な $\delta$ フライトの発生すること, 高速度 鋼や熱間ダイス鋼に晶出する炭化物は $\mathrm{M}_{2} \mathrm{C}$ と $\mathrm{MC}$ で あることなどの興味ある現象が見い出された。

\section{2. 実 験 方 法}

高速度鋼 SKH9 の噴雾粉, SKH9, SKH2 および SKH54 のスプラット, SKH9 およびSKH54 の局部急 冷凝固処理材, 冷間ダイス鋼 SKD11 のスプラット, SKD1 および SKD11 の局部急冷凝固処理材, 熱間ダ イス鋼 SKD61 のスプラットおよび局部急冷凝固処理材 について䑕微鏡観察， $\mathrm{X}$ 線回折，X線マイクロアナライ ザー分析および硬さ測定を実施した，また W, Mo, Cr あるいはVの $1 〜 3$ 種を含む高炭素鋼のスプラットにつ いてX線回折を実施した。

\section{1 実験材料}

\section{$2 \cdot 1 \cdot 1$ 噴霧粉}

この噴霧粉は SKH9 鍛造材届 $50 \mathrm{~kg}$ を大気中で高周 波溶解（溶解温度約 $1550^{\circ} \mathrm{C}$, 溶㓣としてフォセコ, ス
テロットNo 3 を使用）して得た溶湯を噴霧装置のノズ ルから流し，その流れに高压 $\left(50 \mathrm{~kg} / \mathrm{cm}^{2}\right)$ の水を吹き つけて溶湯を飛散させ，粉状に凝固させる方法によつて 福田金属箔粉工業(株)で製作された，水分を除去するた めの乾燥は $100^{\circ} \mathrm{C}$ に温度調節された鉄板上で 30〜60 $\min$ 行なつた. 噴蓩粉の大きさは数 $\mathrm{mm}$ から $325 \times ッ$ シュ以下にわたり，その形状は後の写真に示すように不 規則であり，色は黒褐色である．噴霧粉の化学分析值を 原料として用いた鍛造材とともに Table 1 に示す. 原 料鍛造材と噴霧粉の間には分析值にとくに大きな差は見 られない，噴等粉の化学組成におよほす噴蓩粉の大きさ の影響を見ると $\mathrm{Si}, \mathrm{Mn}, \mathrm{W}, \mathrm{Mo}, \mathrm{Cr}, \mathrm{V}$ については 明確な差がない. またCについても噴罞処理のままの粉 末については分析していないが， $700^{\circ} \mathrm{C} ， 30 \mathrm{~min}$ 水素中 加熱処理した粉末について分析した結果 (Table 2) に よれば噴蓩処理のままの粉末にも大きな $\mathrm{C}$ 量の差はなか つたものと推定される.これに対して噴霧粉にはOが多 くかつOについては粉末の大きさの影響が著しく，粉末 が小さいほどOは少ない。

\section{$2 \cdot 1 \cdot 2$ スプラット}

高周波誘導溶解炉で溶解した溶融金属および浮遊溶解 装置で溶解した 溶融金属を用いてスプラットを製作し た. 前者は $5 \mathrm{~kg}$ 高周波炉（大気中）で溶解した溶湯を 少量ずつひしやくから滴下させ，その落下の途中を 13 $\mathrm{mm}$ 厚銅板の間にはさんで木の葉状または円板状の薄板 に凝固させた. この方法はスプラットクーリング法の中 では Piston and Anvil Technique?) と呼ばれるものに 属する.この方法による冷却速度として Al について $1.5 \sim 3 \times 10^{78)}, 6.9 \times 10^{59)}, \mathrm{Pb}$ について $1.2 \times 10^{6}{ }^{\circ} \mathrm{C} /$ $\sec ^{9)}$ なる值が示されており $10^{6} 〜 10^{7} \mathrm{C} / \mathrm{sec}$ 台と考え て大きな誤りはないであろう・スプラットの厚さは個々 にまた場所によつて差があり，0.5〜1.5 mm，大きさは 10〜 $100 \mathrm{~cm}^{2}$ である.この方法によつて製作したスプラ ットは SKH9, SKH54, SKD11 および SKD61 であ るが溶解原料として SKH9，SKD11，SKD61 の市販材 
それぞれ単独のほか, SKH9 にあらかじめ高周波溶解し て作つた Fe-C と市販の Fe-V を添加して, SKH54の 組成に調合したものを用いた。

後者は $\mathrm{Ar}$ 流中で浮遊溶解した約 $5 \mathrm{~g}$ の溶融金属を 約 $300 \mathrm{~mm}$ の高さから約 $150 \phi \times 60$ の黄銅ブロック上 に落下させて䄪 $0.5 \sim 0.6 \mathrm{~mm}$ 厚さの薄板状に凝固させ

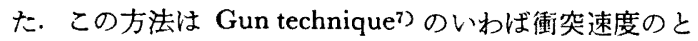
くに小さい場合に相当し, Piston and Anvil technique の場合に比べて冷却速度は小さいと推定されるが前者な みに微細な組織を有している.

このようにして製作したスプラットの分析值をTable 3 に示した. 6-5-4-1 鋼は SKH9 のVを 2\%から1\% に減じたもの，6-5-4-0 鋼は同じくVをなくしたもので これらと SKH9 および SKH54 との比較によつてV量 の影響を調べた・またW鋼および Mo 鋼は状態図的には $\mathrm{M}_{6} \mathrm{C}$ 炭化物を有するもので $\mathrm{W}-\mathrm{V}$ 鋼および Mo-V 鋼 はこれらとの比較によつてやはりV量の影響を見るため のものである. 溶解原料としては SKH9, SKH54, SKH 2 のスプラットを作る場合にはこれらの市販鍛造材, W 鋼, Mo 鋼， V 鋼および 6-5-4-0 鋼のスプラットを作 る場合には電解鉄とフェロアロイを高周波誘導炉で溶解 して砂型に鋳造したものを用いた。 また 6-5-4-1 鋼の
スプラットを作る場合には SKH9 鍛造材と 6-5-4-0 鋼 の鋳造材を，また $\mathrm{W}-\mathrm{V}$ 鋼あるいは Mo-V 鋼のスプラ ットを作る場合にはW鋼の鋳造材あるいは Mo 鋼の鋳造 材とV鋼の鋳造材を等量ずつ配合した.

またスプラットを作るのに用いた高周波誘導溶解炉に よる溶融金属を砂型に鋳込えで比較用の鋳造材を製作し

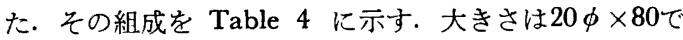
ある.

\section{$2 \cdot 1 \cdot 3$ 局部急冷凝固処理材}

局部急冷凝固処理は（a）電子ビーム，(b) 移送型プ ラズマ, (c) タングステン電極不活性ガスアーク (TIG アーク)，(d) 放電および (e) 高周波誘導加熱によつて 実施した。これらの熱源によつて加熱され溶融後凝固し た層を局部急冷凝固層と呼ぶことにした.

電子ビームによる局部急冷凝固処理は（A)，（B）お よび（C）の 3 つシリーズに分けて行ない（A）実験

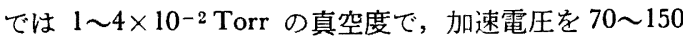

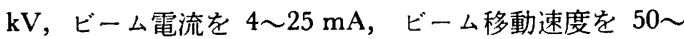
$3250 \mathrm{~mm} / \mathrm{min}$ の範囲で変化させて, 長さ $100 \mathrm{~mm}$ ま たは $165 \mathrm{~mm}$ の直線状の局部急冷凝固層を作つた.母 材として使用した工具鋼は Table 5 に示す SKH9 $(8 \cdot 5$ mm 厚さ)，および SKD1（13 mm 厚さ）の板材であ

Table 3. Chemical composition of splats (\%).

\begin{tabular}{|c|c|c|c|c|c|c|c|c|c|}
\hline & $\mathrm{C}$ & $\mathrm{Si}$ & $\mathrm{Mn}$ & $\mathbf{W}$ & Mo & $\mathrm{Cr}$ & V & $\mathrm{P}$ & $\mathrm{S}$ \\
\hline S KH 9 & $0 \cdot 90$ & $0 \cdot 31$ & $0 \cdot 32$ & 6.05 & $4 \cdot 53$ & $3 \cdot 85$ & $1 \cdot 86$ & 0.023 & $0 \cdot 006$ \\
\hline S KH 2 & $0 \cdot 74$ & $0 \cdot 35$ & $0 \cdot 36$ & $18 \cdot 25$ & - & $4 \cdot 23$ & $1 \cdot 00$ & 0.012 & 0.006 \\
\hline $\mathrm{S} \mathrm{KH} 54 * * *$ & $1 \cdot 33$ & 0.25 & 0.35 & 6.0 & $5 \cdot 0$ & 4.15 & $4 \cdot 2$ & $* *$ & $* *$ \\
\hline $6-5-4-0$ & $0 \cdot 86$ & $* *$ & $* *$ & $5 \cdot 72$ & $5 \cdot 00$ & $3 \cdot 98$ & - & ** & $* *$ \\
\hline $6-5-4-1$ & $0 \cdot 88^{*}$ & $* *$ & ** & $5 \cdot 88 *$ & $4 \cdot 77 *$ & $3 \cdot 92 *$ & $0 \cdot 98 *$ & $* *$ & $* *$ \\
\hline W Steel & $1 \cdot 21$ & ** & ** & $26 \cdot 4$ & - & - & - & $* *$ & $* *$ \\
\hline Mo Steel & $1 \cdot 27$ & $* *$ & $* *$ & - & $26 \cdot 1$ & - & - & $* *$ & $* *$ \\
\hline W-V Steel & $1 \cdot 21 *$ & $* *$ & $* *$ & $1 \cdot 34 *$ & - & - & $0 \cdot 96 *$ & $* *$ & $* *$ \\
\hline Mo-V Steel & $1 \cdot 24 *$ & $* *$ & $* *$ & - & $13 \cdot 1 *$ & 一 & $0.96 *$ & ** & $* *$ \\
\hline V Steel & $1 \cdot 21$ & $* *$ & ** & - & - & - & $1 \cdot 92$ & $* *$ & $* *$ \\
\hline
\end{tabular}

* Calculated ** Not determined *** Nominal composition

Table 4. Chemical composition of sand castings (\%).

\begin{tabular}{|c|c|c|c|c|c|c|c|}
\hline & $\mathrm{C}$ & $\mathrm{Si}$ & $\mathrm{Mn}$ & W & Mo & $\mathrm{Cr}$ & $\mathrm{V}$ \\
\hline $\begin{array}{ll:l}\mathrm{S} & \mathrm{KH} & 9 \\
\mathrm{~S} & \mathrm{KH} & 54 \\
\mathrm{~S} & \mathrm{~K} \mathrm{D} & 11 \\
\mathrm{~S} & \mathrm{~K} \mathrm{D} & 61\end{array}$ & $\begin{array}{l}0 \cdot 75 \\
1 \cdot 27 \\
1 \cdot 44 \\
0 \cdot 37\end{array}$ & $\begin{array}{l}0 \cdot 25 \\
0 \cdot 29 \\
0 \cdot 27 \\
0 \cdot 89\end{array}$ & $\begin{array}{l}0 \cdot 29 \\
0 \cdot 29 \\
0 \cdot 25 \\
0 \cdot 35\end{array}$ & $\begin{array}{c}6 \cdot 30 \\
5 \cdot 44 \\
- \\
-\end{array}$ & $\begin{array}{l}4 \cdot 88 \\
4 \cdot 22 \\
0 \cdot 91 \\
1 \cdot 29\end{array}$ & $\begin{array}{r}4 \cdot 09 \\
4 \cdot 00 \\
11 \cdot 86 \\
5 \cdot 17\end{array}$ & $\begin{array}{l}2 \cdot 02 \\
3 \cdot 94 \\
0 \cdot 32 \\
0 \cdot 96\end{array}$ \\
\hline
\end{tabular}

Table 5. Chemical composition of steels used for electron beam and transfer-plasma melting $(\%)$.

\begin{tabular}{|c|c|c|c|c|c|c|c|c|c|c|c|}
\hline & C & $\mathrm{Si}$ & $\mathrm{Mn}$ & $\mathbf{P}$ & $\mathrm{S}$ & W & Mo & $\mathrm{Cr}$ & V & $\mathrm{Ni}$ & $\mathrm{Cu}$ \\
\hline SKH 9 & 0.90 & $\begin{array}{l}0.26 \\
0.23\end{array}$ & 0.30 & 0.022 & $\begin{array}{c}0.004 \\
0.007\end{array}$ & $6 \cdot 33$ & $4 \cdot 77$ & $\begin{array}{r}3 \cdot 74 \\
\end{array}$ & $1 \cdot 93$ & $0 \cdot 12$ & 0.07 \\
\hline SKD61 (Wadded) & $0 \cdot 34$ & 0.99 & $0 \cdot 39$ & 0.006 & 0.005 & $1 \cdot 57$ & $1 \cdot 49$ & $5 \cdot 10$ & 0.95 & - & $0 \cdot 15$ \\
\hline
\end{tabular}


る. (B) 実験では 30〜36 $\phi \times 90$ の SKH9，SKD1 お よび SKD11 の端面に直径 $20 \mathrm{~mm}$ のリング状の局部急 冷凝固層を作つた：溶融条件として SKH9 については,

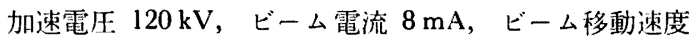
$915 \mathrm{~mm} / \mathrm{min}, \mathrm{SKDl}$ および SKDll については 150 $\mathrm{kV} ， 8 \mathrm{~mA} ， 915 \mathrm{~mm} / \mathrm{min}$ を選んだ. また溶融開始部と 終了部が重ね合わさつた部分に割れの発生を防ぐため, 一部は $400^{\circ} \mathrm{C}$ に予熱した。 真空度は $10^{-2}$ Torr 台で ある. (C) 実験では $40 \times 30 \mathrm{~mm}$ 角の SKD61（1.5\%の Wを加えて改良したもの), $8.5 \mathrm{~mm}$ 厚さの $\mathrm{SKH} 9,1 \cdot 3$ $\mathrm{mm}$ 厚さの SKD1 板材 (Table 5 参照) 上に約 $2 \times$ 10-4 Torr 真空下で加速電圧 24〜30kV, ビーム電流 60 $\sim 120 \mathrm{~mA}$, ビーム移動速度 $2000 \sim 160 \mathrm{~mm} / \mathrm{min}$ の条 件で, 長さ $70 〜 250 \mathrm{~mm}$ の直線状のビードを作つた.

移送型プラズマによる局部急冷凝固処理はプラズマ作 動用アルゴンガス $2 l / \mathrm{min}$, シールド用アルゴン $15 l /$ $\min$ ，ノズルと試験片表面の間隔 $4 \mathrm{~mm}$ の条件下でプ ラズマ電流を $70 \mathrm{~A}$ または $80 \mathrm{~A}$ ，移動速度を 80 〜00 $\mathrm{mm} / \mathrm{min}$ に変化させて長さ $100 \mathrm{~mm}$ または $160 \mathrm{~mm}$ の 直線状の局部急冷凝固層を作つた，母材は電子ビームに よる局部急冷凝固处理に用いられたものと同じである.

TIG 溶接機汇上る局部急冷凝固処理では，アーク電 流を 16〜 50A (正極性) アルゴンガス流量を 10〜20l/ min，台材と電極間の距踓を 4 10 $\mathrm{mm}$ に変化させて 長さ約 $50 \mathrm{~mm}$ の直線状の局部急冷凝固層を作つた．鋼
材は SKH9 である.

高周波誘導加熱による局部急冷凝固処理では $36 \phi$ の SKH9 の市販解造材を $40 \phi 3$ 卷きのコイル中に置き, $400 \mathrm{kC}$ の周波数で一部が溶融し，溶け落ちる寸前まで $(20 \sim 30 \mathrm{sec})$ 加熱後空冷した．局部急冷凝固層は約 $5 \mathrm{~mm}$ の深さ，約 $7 \mathrm{~mm}$ 幅のリング状である.

放電加熱による局部急冷凝固处理では $10 \phi \times 10 \mathrm{~mm}$ の高速度鋼 SKH 9 鍛造材の端面の一部に先端を円錐状 に加工した SKH 9 鍛造材を 6.5V の交流を售荷した 状態で, 瞬間的に接触させて, $0.5 \mathrm{~mm} \phi$ 程度の表面積 を持つ局部急冷凝固層を作つた。

局部急冷凝固相は凝固に先立つてまず溶融状態におか れるが，電子ビームやプラズマによる場合には溶融温度 も一般の溶解に比べて高温であるので，処理の間に多少 の組成の变化が生ずる可能性がある。これを確かめるた めに電子ビームおよび移送型プラズマによる凝固のまま の局部急冷凝固層についてX線マイクロアナライザー分 析を行なつた．化学分析を行なわなかつたのは，局部急 冷凝固層が小さくて分析試料の採取が困難なためであ る. X線強度から重量\%を決定するのには化学分析值の わかつている母材を標準試料として比例計算した。偏析 の影響をさけるためにビーム径を $100 〜 150 \mu$ としCお 上び Si については 12 回(12個所)，そのほかの元素に ついては 6 回 ( 6 個所)の平均値を取つた. このようにし て得られた分析值は Table 6 のとおりである.

Table 6. Change of chemical composition after electron beam or transfer-plasma melting.

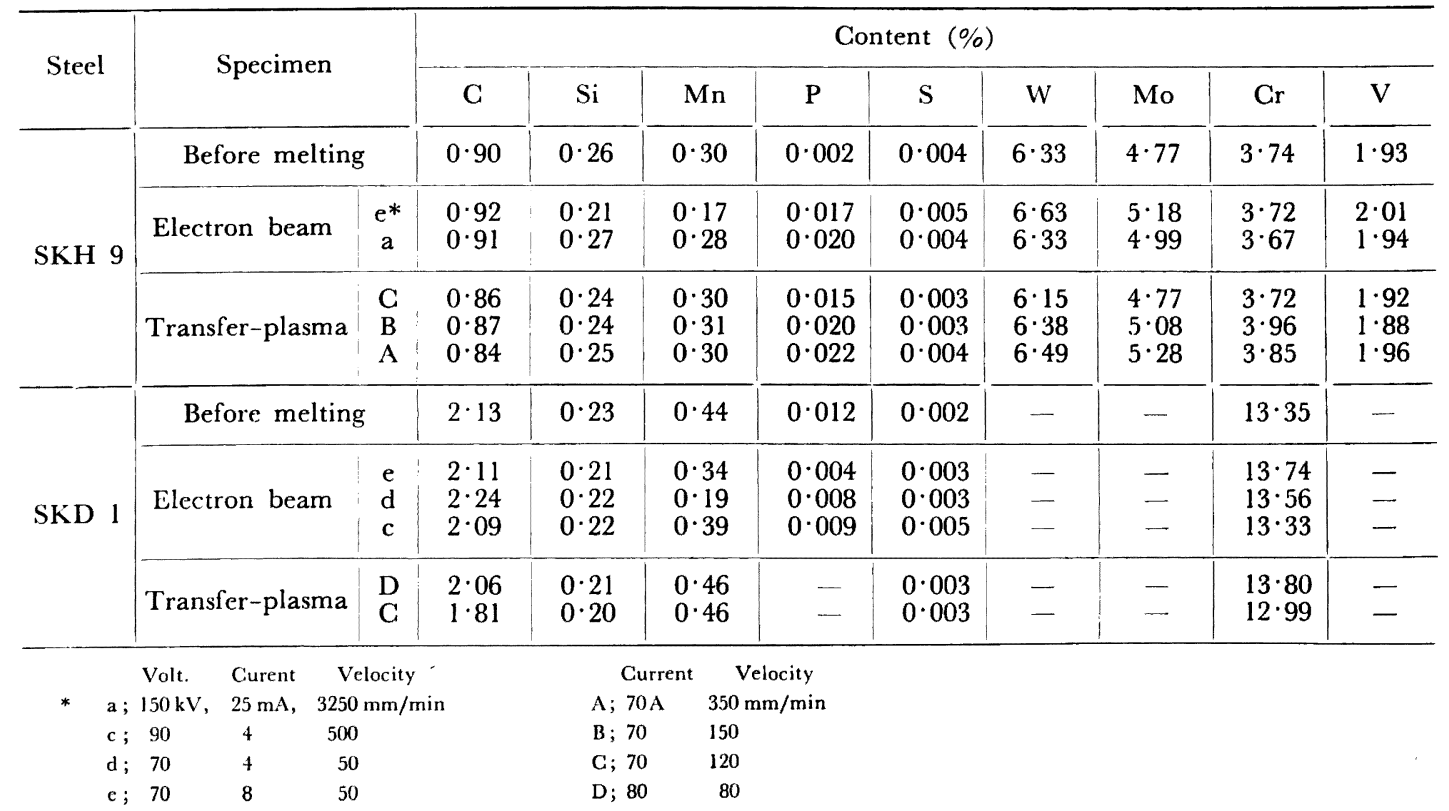




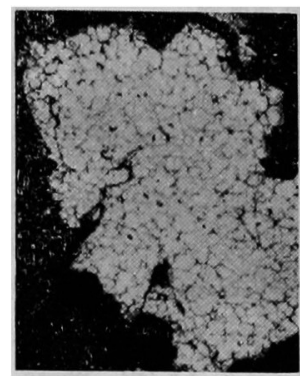

(a) 20 100 mesh, $\times 400^{27}$

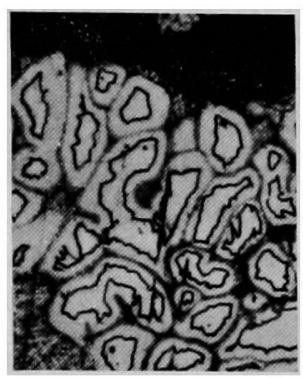

(d) $20 \sim 100$ mesh, $\times 400$

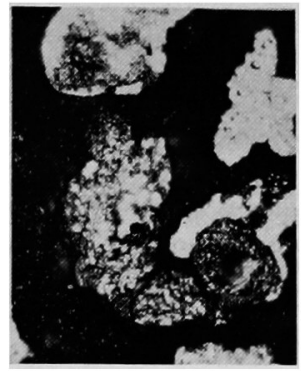

(g) 250-325 mesh, $\times 400^{7 x}$

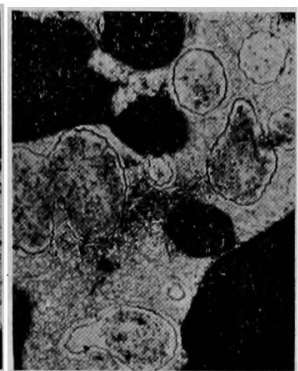

(b) 20-100 mesh, $\times 400$

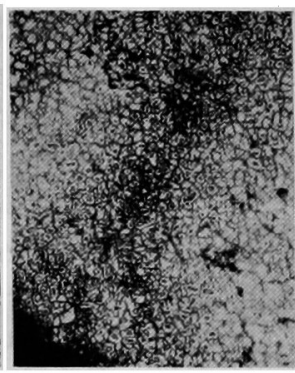

(e) $20 \sim 100$ mesh, $\times 400$

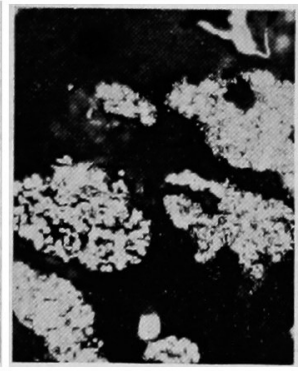

(h) $250-325$ mesh, $\times 400^{28}$

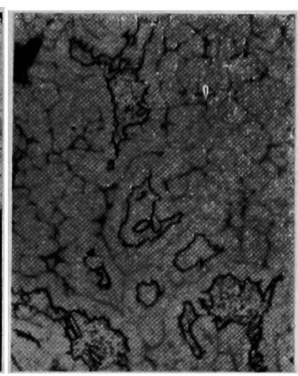

(c) 20 - 100 mesh, $\times 400^{12}$

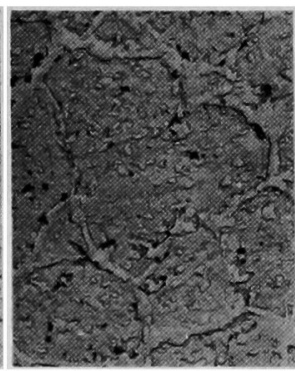

(f) $20-100$ mesh, $\times 5000^{4 *}$

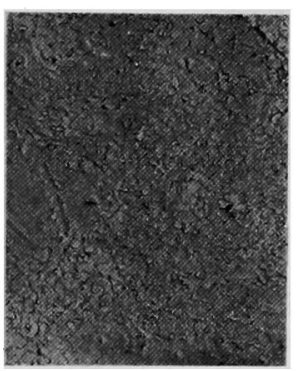

(i) 250 325 mesh, $\times 5000$

Photo. 1. Microstructures of SKH9 atomized powders.

(* Murakami's reagent etch, ** Nital etch) (3/5)

電子ビームによる局部急冷凝固層では SKH9, SKD1 ともに $\mathrm{P}$ と $\mathrm{Mn}$ が隇少し, その減少量は局部急冷凝固 層の体積の大きいほど大きい傾向がみられる.（局部急 冷缶固層の大きさについては Photo. 3，4，10 および 11に示してある) 移送型プラズマによる場合には C と $\mathrm{P}$ が減少する傾向が見られる．PおよびMnの隇少は工具 鋼としてはむしろ望ましい10)ことである，Cの減少は熱 処理硬さを低下させる11ので望ましいことではないがこ の程度ならば問題はないであろう。

\section{$2 \cdot 2$ 顕微鏡観察および硬さ測定}

すべての材料について凝固のままの組織を光学顥微鏡 あるいは電子顕微鏡で観察したが，とくに噴霧粉につい ては下記のような熱処理を施した粉末をも観察の対象と
した.

（a） $575^{\circ} \mathrm{C}$ または $600^{\circ} \mathrm{C}$ の温度で $1 \mathrm{hr}$ 加熱後空 冷の焼もどしを 2 回繰り返し

（b）減圧下 $\left(10^{-2}\right.$ Torr) で $890^{\circ} \mathrm{G} に 5 \mathrm{hr}$ 加熱後 炉冷（この処理によつてCが $0.40 \%$ まで減少した）

（c）水素中で $1000^{\circ} \mathrm{C}$ に $30 \mathrm{~min}$ 加熱後炬冷（こ

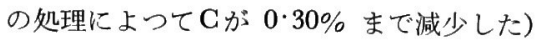

(d) 黒鉛粉 $1 \%$ 添加後水素中で $1100^{\circ} \mathrm{G} 2 \mathrm{hr}$ 加熱 後炉冷（この処理では $\mathrm{C}$ 量は変化しなかつた）

また凝固のままおよび（a）の処理を施した粉末につ いて微小硬さを測定した。

\subsection{X線マイクロアナライザー分析}

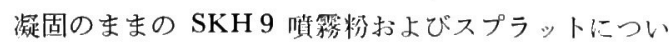




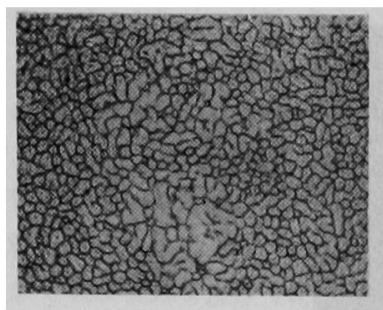

(a) $\mathrm{SKH9} \times 1000$

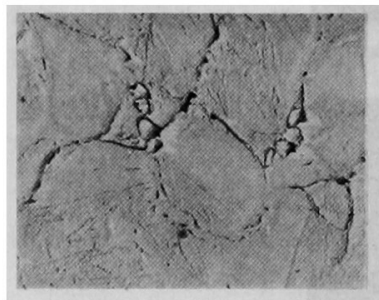

(c) SKH9 $\times 5000$

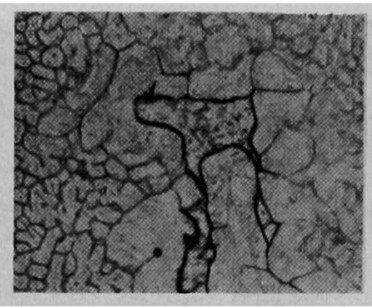

(b) SKH9 $\times 1000$

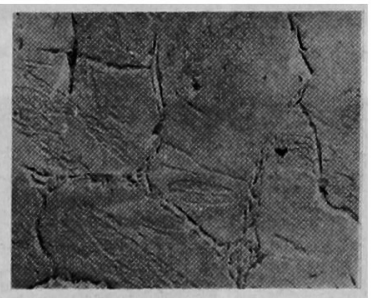

(d) $\mathrm{SKH9} \times 5000$

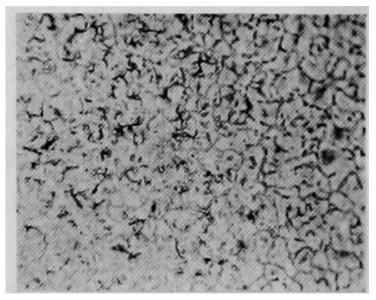

(e) SKH54 $\times 1000$

Photo. 2. Microstructures of SKH9 and SKH54 splats. (Nital etch). (3/5)

て線分析を行ない，合金元素の分布を調べた. 加速電 圧 : $30 \mathrm{kV}$, 試料電流 : $0.06 \mu \mathrm{A}$, 電子線径: $1 \sim 2 \mu$, 試 料送り: $2 \mu$ ステップ, または $8 \mu / \min$ の条件で, 標 準試料として W, Mo, Cr については純金属, Vにつ いては V-Al，Gについては 1.07\% C の Fe-C を使用 した.

\section{$2.4 \mathrm{X}$ 線回折}

凝固のままの SKH 9 噴霧粉および各鋼のスプラット についてX線回折を行なつた. また SKH 9 の噴霧粉お よびスプラットについては, $100 \sim 900^{\circ} \mathrm{C}$ の温度に $2 \mathrm{hr}$ 加熱後空泠したものを対象とした．炭化物の同定を目的 とする場合には, 噴霧粉については室温の $\mathrm{HCl}$ 水溶液 (1：1) 中に $24 \mathrm{hr}$ 浸漬後, ろ過した溶解残査を, スプ ラットについては 0.1 NHCI 溶液による電解分㜠残査 をも試料とした．主として $\mathrm{Fe}, \mathrm{Cr}$ あるいは $\mathrm{Co} の \mathrm{~K}_{\alpha}$ 線を用いてX線回折した.

\section{3. 実 験 結 果}

\section{$3 \cdot 1$ 顕铰鏡組織}

\section{$3 \cdot 1 \cdot 1$ 高速度鋼}

Photo. 1 は凝固のままの SKH9 䠝霧粉, Photo. 2 は凝固のままの SKH9, SKH54 スプラット, Photo. 3 は電子ビームによる凝固のままのSKH9, SKH54 局部急冷凝固層, Photo. 4 は移送プラズマ による凝固のままのSKH9 局部急冷凝固層, Photo. 5 は放電, 高周波誘導加熱および TIG アークによ る凝固のままの SKH9, 局部急冷凝固層, Photo. 6 は凝固のままの SKH9, Photo. 7 は市販の SKH9, SKH54 鋳造材(焼なましずみ) の光学顕微鏡あるい は電子顕微鏡組織写真である. Photo. 3 および 4 に は局部急冷凝固層の断面形状も併記してある. これ らの写真より明らかなことは以下のとおりである.

（1）急冷凝固した高速度鋼の組織はPhoto. 1 a および $\mathrm{f} に$ 典型的に見られるように炭化物が網状に 分布した組織からなつているが，比較的冷却速度の 小さいと考えられる高周波誘導加熱および移送プラ ズマによる局部急冷凝固層や電子ビームでもとくに 断面が大きい場合には，この網目を形成する炭化物 が砂型鋳造材の炭化物と同じく縞状の共晶組織とな つている. また冷却速度の大きいと考えられる粒度 の小さい噴霧粉では Photo. 1 i のように炭化物は 粒状に近い形となり網目が不明りようである.

（2）噴霧粉には内部に微細な粒状相を持ち，上 記の網状炭化物からなる組織とは明らかに異なつた 相が多数認められる.この相（以下非網状相と仮称 する) は Photo. 1 bのように滑らかな丸味を帯びてい

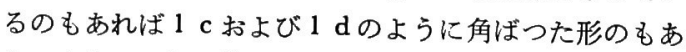

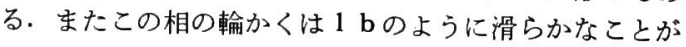
多いが， $1 \mathrm{c}$ や1 d のように入りくんだ不規則な形のこ ともある.この相の大きさは $1 \mathrm{~b} \sim 1 \mathrm{~d}$ に見られるよう な数 $10 \mu$ 以上のものが大部分であるが $1 \mathrm{e}$ に見られる

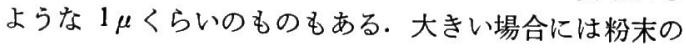
体積の大部分がこの相で占められているように見えるが この相を持つた粉末の数は持たない粉末にくらべてはる かに少ない，またこの相を持つた粉末は粒度の大きい粉 末に多いようである.

この非網状相は Photo. 2 bのようにスプラットの中 にもごくわずかに認められたが，これはたまたま部分的 に厚さ不同の生じた場合のとくに厚い部分に存在した.

また局部急冷㠜固層にもしばしば認められた. その存 在位置は局部急冷凝固層の最後に凝固が行なわれると推 定される部分である. また Photo. 5 a のように放電に よる局部急冷凝固層にもわずかに認められる. 存在位置 から非網状相は喷霧粉, スプラット, 局部急冷凝固層の 


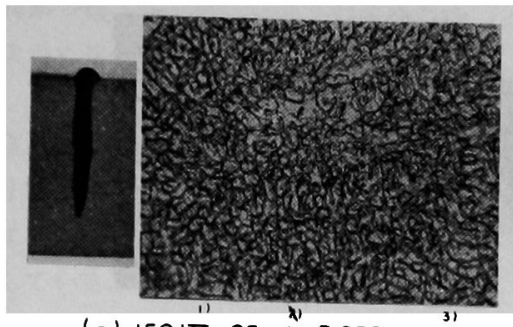

(a) $150 \mathrm{kV}, 25 \mathrm{~mA}^{\prime \prime}, 3250 \mathrm{~mm} / \mathrm{m}^{3 \prime}$

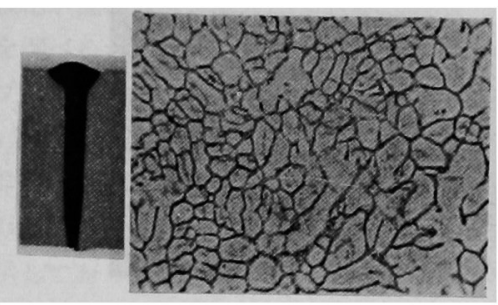

(b) $120 \mathrm{kV}, 17 \mathrm{~mA}, 1000 \mathrm{~mm} / \mathrm{min}$

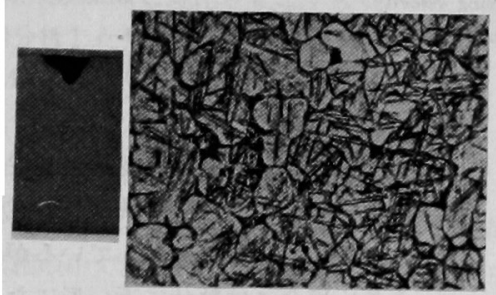

(c) $90 \mathrm{kV}, 4 \mathrm{~mA}, 500 \mathrm{~mm} / \mathrm{min}$

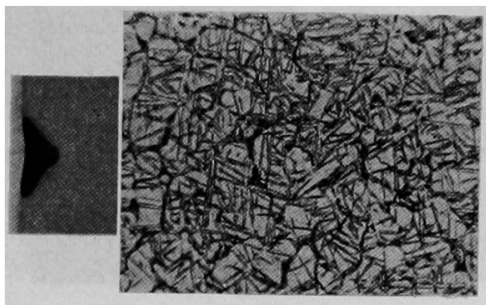

(d) $70 \mathrm{kV}, 4 \mathrm{~mA}, 50 \mathrm{~mm} / \mathrm{min}$

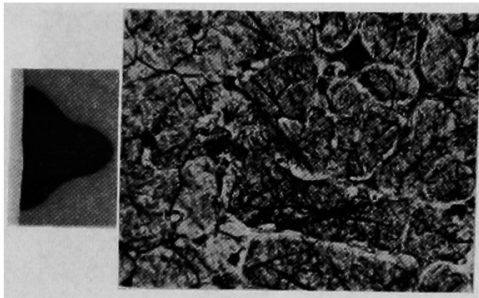

(e ) $70 \mathrm{kV}, 8 \mathrm{~mA}, 50 \mathrm{~mm} / \mathrm{min}$
1) accelated voltagc
2) beam current
3) moving velocity

Photo. 3. Microstructures of SKH9 bead made by electron beam melting. $($ Nital etch, Microstructure $\times 1000$, Cross section $\times 4)(3 / 5)$

中で比較的冷却速度の小さい部分に発生したと考えられ る.

またこの非網状相の付近を詳細に観察してみると網状 相が大きい場合 (Photo. $1 \mathrm{~b}, 1 \mathrm{c}, 1 \mathrm{~d}$ ) でも，小さい 場合 (Photo. $1 \mathrm{e}, 5 \mathrm{a}$ ) でも, 前記網状相の炭化物で 形成された一つの網目の中心部に非網状相が位置してい ることがわかる。

このことから非網状相は網目を形成する炭化物に先行 して晶出したと推定される.

非網状相の内部には村上試薬による腐食では認められ ない(Photo. $1 \mathrm{~d}$ ) が，硝酸アルコール腐食では微細な 粒が全面に見られる. (Photo. $1 \mathrm{~b}, 1 \mathrm{c}, 2 \mathrm{~b}$ )

（3）高周波誘導加熱による局部急冷凝固層を除いて は, 硝酸アルコール溶液によつて基質部はほほ一様に腐 食され，砂型鋳造材に見られるような腐食組織を示さな い.したがつて基質部はほほ均一な組成を持つている可 能性が考えられる.
（4）高周波誘導加熱による局部急冷凝固相は，組織 が多少微細な以外は鋳造材と類似した組織である.

（5）炭化物の網目の大きさは粒度の小さい噴霧粉に

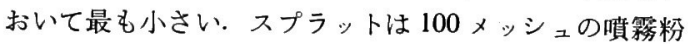
とほぼ同じくらいである. 放電に上る局部急冷凝固層は 微細な噴霧粉なみである. TIG アークやプラズマによ る局部急冷凝固層では溶融条件を变化させても網目の大 きさは大きく変化せず，20１00 メッシュの噴霧粉より はるかに大きい網目である．また電子ビームによる局部 急冷㠜固層では，条件を変えることによつて粒度の小さ い噴霧粉に相当する微細さから，大きな噴霧粉よりもさ らに大きいところまで変化した. 加速電圧を高く, ビー ム移動速度を大きくして, 幅のせまく, 溶込みの深い断 面形状にするほど微細となる傾向が認められる.

(6) SKH54 と SKH9 の間には本質的な組織の差 は認められない. SKH54 の方に粒状の炭化物が多いだ けである.これは砂型鋳造材においても同じで，粒状の 


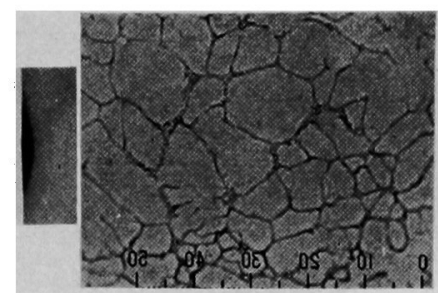

(a) $70 A^{\prime \prime}, 350 \mathrm{~mm} / \mathrm{min}^{2}$

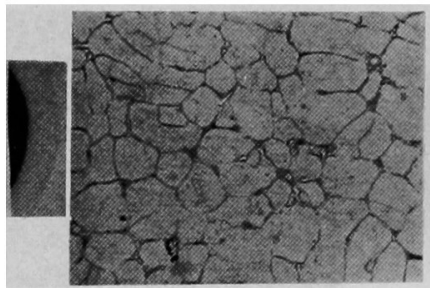

(b) $70 \mathrm{~A}, 150 \mathrm{~mm} / \mathrm{min}$

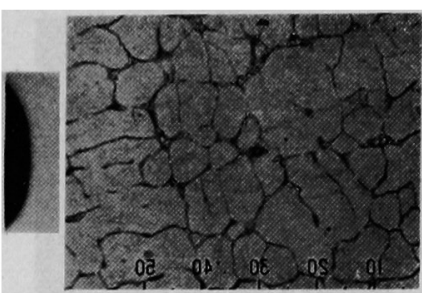

(c) $70 \mathrm{~A}, 120 \mathrm{~mm} / \mathrm{min}$

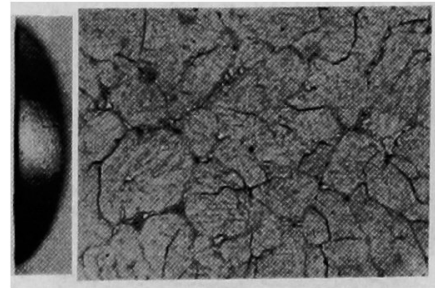

(d) $80 \mathrm{~A}, 80 \mathrm{~mm} / \mathrm{min}$

2) plasma current 2) moving velocity

Photo. 4. Microstructures of SKH9 beads made by transfer plasma. (Nital etch, Microstructure $\times 1000$, Cross section $\times 4)(3 / 5)$

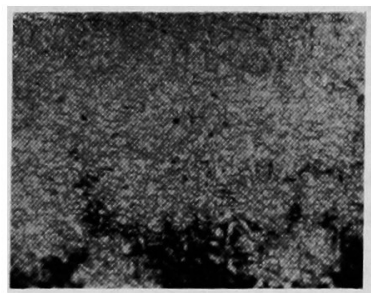

(a) Spark $\times 1000$

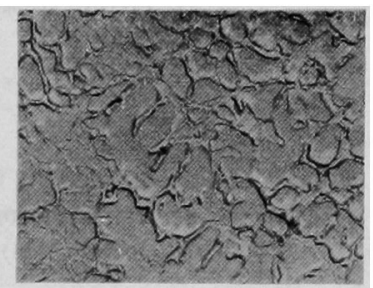

(b) Spark $\times 5000$

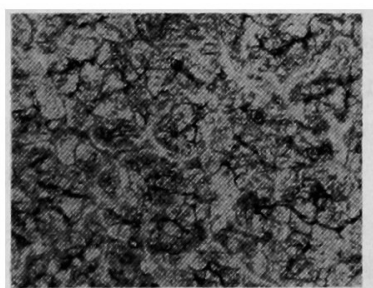

(c) High frequency induction $\times 400$

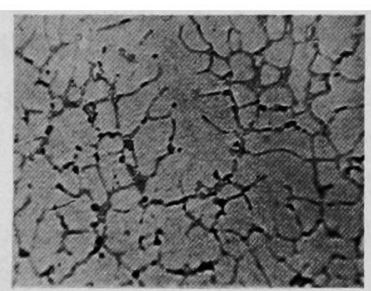

(d) TIG arc (current $30 \mathrm{~A}$ moving velocity $50 \mathrm{~mm} / \mathrm{min}) \times(000$
Photo. 5. Microstructures of rapidly quenched layers SKH9 melt made by electric spark, high frequency induction heating and TIG arc. (Nital etch) (3/5)
（8）急冷凝固高速度鋼中の炭化物は, 冷却 速度の小さい場合には鋳造材の炭化物と同じよ うに板状で縞状に分布しているが，冷却速度が 大きい場合には粒状に近い形になる.

凝固のままの組織の観察によつて以上の諸点 が明らかになつたが，さらに理解を容易にする ために種々の熱処理を加えた SKH 9 噴霧粉の 組織を観察した. Photo. 8 a および 8 c は 575 ${ }^{\circ} \mathrm{C}$ あるいは $600^{\circ} \mathrm{C} 1 \mathrm{hr}$ 空冷の焼もどしを 2 回行なつた粉末の組織であつて，基質が焼もど しされて腐食されやすくなつている．基質の腐 食のされ方は一様でなく，基質には組成の不均 一があると推定される. また非網状相の中には 8 a に見られるように針状の方向性を持つた析 出物がしばしば認められた. $8 \mathrm{c}$ および $8 \mathrm{~d} は$ 減圧下で $890^{\circ} \mathrm{C} に 5 \mathrm{hr}$ 加熱（この処理によつ て C が 0.40\% まで咸じている)，8 e および $8 \mathrm{f}$ は水素中で $1000^{\circ} \mathrm{C}$ に $30 \mathrm{~min}$ 加熱 ( $\mathrm{C}$ が $0 \cdot 30 \%$ に減じている) された粉末の組織であ るが，この加熱によつても非網状相内には多く の粒状晶の析出が認められる。粒状晶が $8 \mathrm{e}$ のように 方向性を孔つて配列している場合と, $8 \mathrm{c}, 8 \mathrm{~d}$ や $8 \mathrm{f}$ のように明確な方向性がない場合がある. $8 \mathrm{~g}$ および 8 h は黒鉛粉を添加して $1100^{\circ} \mathrm{G} 1 \mathrm{hr}, \mathrm{H}_{2}$ 中で加熱した 粉末の組織である（C 量には変化がなかつた）が， $8 \mathrm{~g}$ 
のように炭化物が一様に網日状に分布した組織のほ かに, $8 \mathrm{~h}$ のように炭化物の少ない部分も存在して いる.

Photo. 8 によれば噴蓩粉を变態点以上の高い温度 に加熱後徐椧すると凝固のままでは細長い形状で網 目を形成するように分布していた炭化物が，きれい な粒状に変化している.これは実用上望ましいこと である。

つぎに非網状相が他の部分と異なつた組成を持つ ているか否かを調べるために EPMAによる線分析 を SKH 9 スプラットおよび噴霧粉について行なつ た. Fig. 1 および Fig. 2 はスブラットについて 中央で大きな非網状相を横切るようにビームを動か した結果で，Fig. 1では Mo とVはほとんど同一 の増隇傾向学示しており， Gr もこれとほぼ同じで ある.また Fe はこれらの多い部分で少ない，この Fig. 1 および顐微鏡組織と対比させながら $\mathrm{C}, \mathrm{W}$, Moについて線分析した Fig. 2 から，網目の部分 には C, W, Mo, Cr，V が多いことが明らかで， 網目を形成する相は W，Mo， Cr，V からなる炭 化物である. 非網状相の部分は Fe がやや高目であ ることからこれらの合金元素が他に比べて少ないと判断 される. 非網状相の中では W，Mo，VC Cr とくに前三 者の変化は見られないがCのみは相当に変化している.

これらは噴霧粉の場合についてもまつたく同じ傾向であ つて，Fig. 3 に示すとおりである. Fig. 2，Fig. 3 とも に非網状相の微粒とCの変化の対比は明確でないが, 微 粒は W, Mo, Cr, V に乏しい炭化物である可能性も ある・

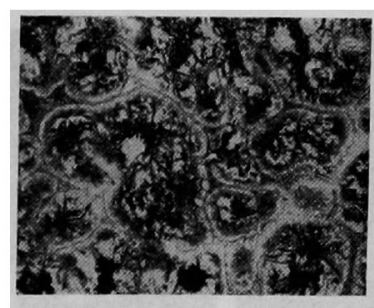

(a) SKH9 $\times 400$

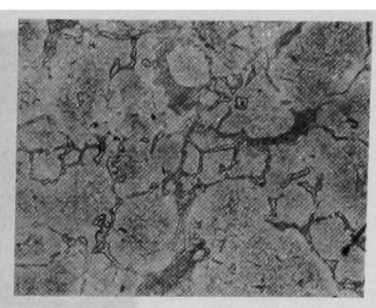

(b) SKH54 $\times 400$

Photo. 6. Microstructures of SKH9 and SKH54 castings. (Nital etch) $(3 / 5)$

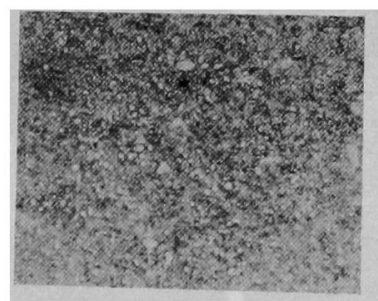

(a) SKH9 $\times 400$

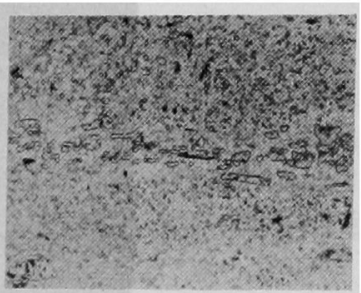

(b) SKH54 $\times 400$

Photo. 7. Microstructures of SKH9 and SKH54 forged bars. (Nital etch) $(3 / 5)$

いて非網状相および非網状相の微小硬さを測定したとこ ろ，非網状相は凝固のままで Hv 459〜 572 × 508， 575 ${ }^{\circ} \mathrm{C}, 1 \mathrm{hr}, 2$ 回の焼もどし後で $530 \sim 620 \bar{x} 553$, 網状 相からなる部分はそれぞれ 835〜974 ×873，824〜907 869 であつた. 非網状相の硬さは低く，焼もどしによつ てもあまり変化しない。

\section{$3 \cdot 1 \cdot 2$ ダイス鋼}

Photo. 9 は凝固のままの SKD11 および SKD61の

つぎに大きな粒度（約 $2 \mathrm{~mm}$ ) の SKH 9 噴蓩粉につ

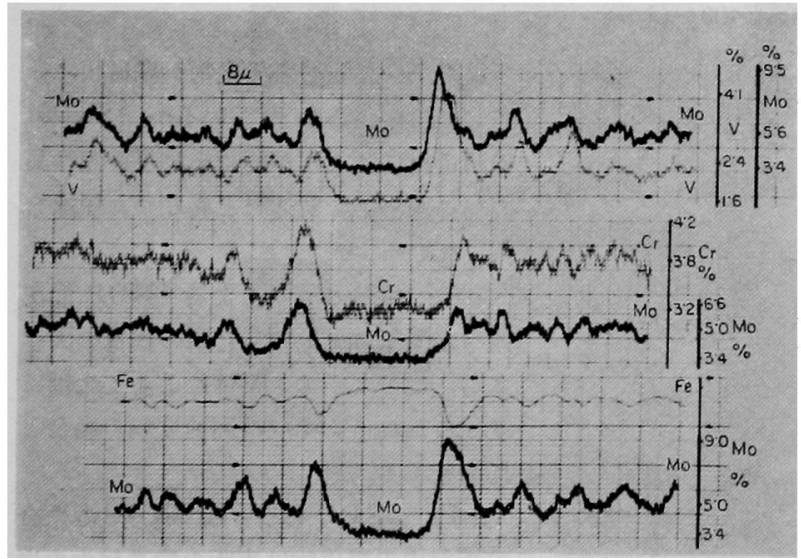

Fig. 1. Charts of line analysis obtained from SKH9 splat.
電子ビームによる局部急冷㐨固屏，(SKD61 いては省略した）Photo. 11 は凝固のままのSKD 1 の移送プラズマによる局部急冷凝固層, Photo. 12は凝固のままの SKD11，SKD61 の砂型鋳造 材, Photo. 13 は市販の SKD1, SKD11, SKD61 の鍛造材（焼なましずみ）の光学顕微鏡による組 織写真である.これらの写真より明らかな点は以 下のとおりである.

（1）冷間ダイス鋼 SKD1 および SKD11の スプラットあるいは局部急冷凝固層は鋳造材と同 じく炭化物が網状に分布した組織から成つてい る.しかし網目の大きさおよび網目を形成する炭 化物個々の大きさは鋳造材に比べて小さい.

（2）熱間ダイス鋼 SKD61 のスプラットおよ 


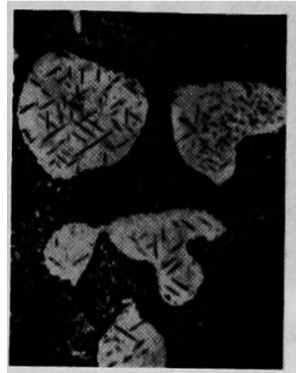

(a) $575^{\circ} \mathrm{C} \times 1 \mathrm{hr} \times 2, \mathrm{AC}$

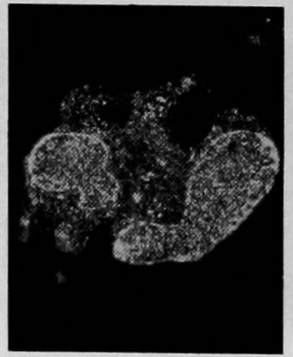

(d) Same as (c)

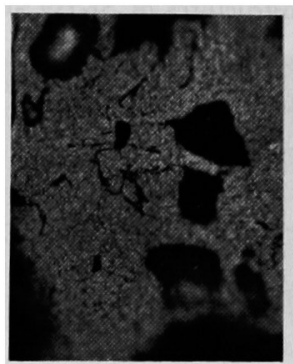

(g) $1100^{\circ} \mathrm{C} \times 1 \mathrm{hr}$ in $\mathrm{H}_{2}$

slow cooled lotter

$1 \%$ graphite powder added)

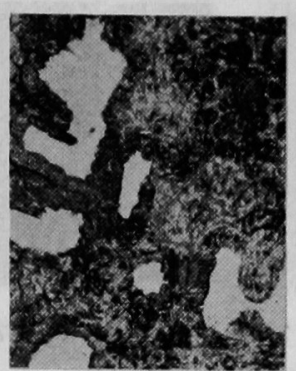

(b) $600^{\circ} \mathrm{C} \times 1 \mathrm{hr} \times 2, \mathrm{AC}$

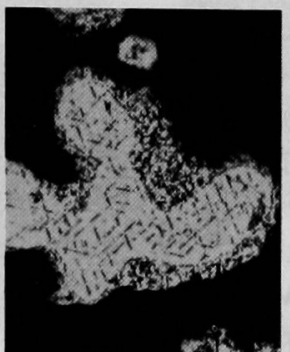

(e) $1000^{\circ} \mathrm{C} \times 0.5 \mathrm{hr}$ in $\mathrm{H}_{2}$ slow cooled

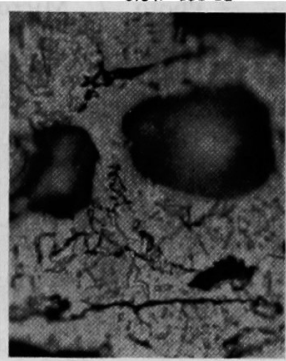

(h) Same as (g)

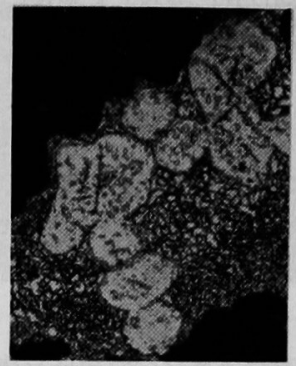

(c) $890^{\circ} \mathrm{C} \times 5 \mathrm{hr}$, slow cooled

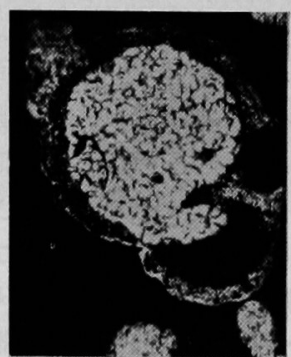

(f) Same as (e)

Fig. 8. Microstructures of SKH9 atomized powders after heat treatment. $(20 \sim 100$ mesh, Nital etch $\times 400)(3 / 5)$

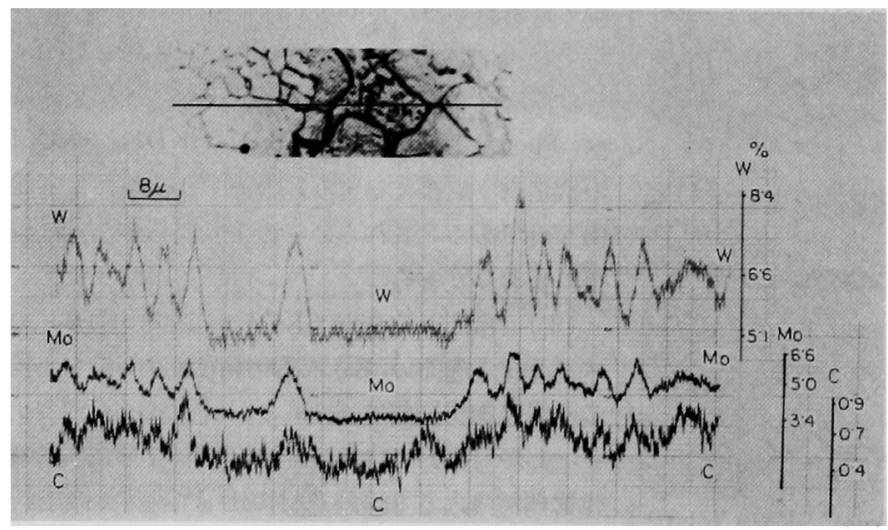

Fig. 2. Same as Fig. 1.
び局部急冷凝固層も炭化物が網目状に分 布した組織からなつているが，SKD61 の鋳造材にはこれが認められず，急冷凝 固材は明らかに錆造材と異なつた組織を 持つている.

(3) 電子ビームによる SKD1 局部 急冷凝固層における炭化物の網目の大き さは，電子ビームの条件によつて大幅に 変化したそその傾向は高速度鋼の場合と 同じである.

(4) SKD1 あるいは SKD11の急冷 凝固材中の炭化物は市販の鍛造材中の炭 化物に比べて微細である. 


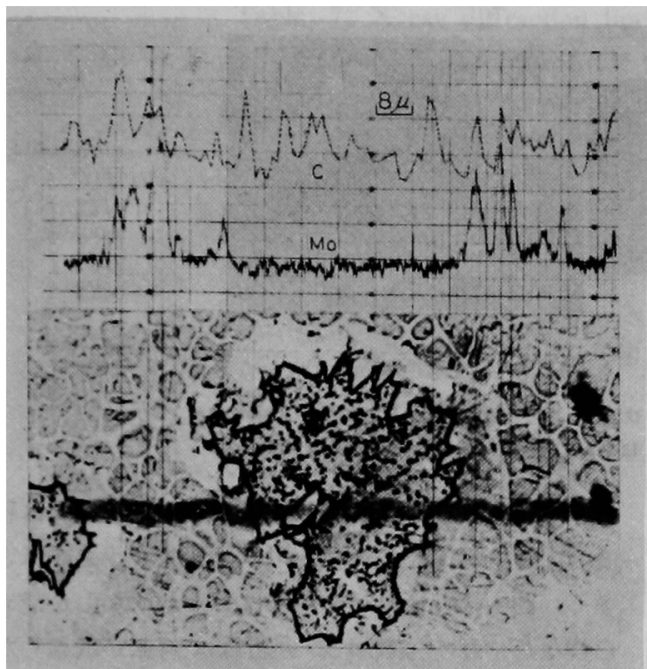

Fig. 3. Chart of line analysis obtained from SKH9 atomized powder.

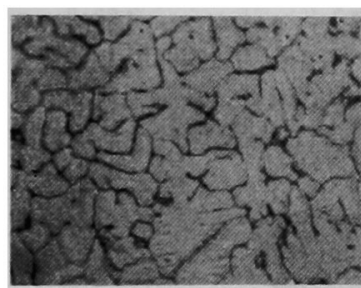

(a) SKD II $\times 1000$

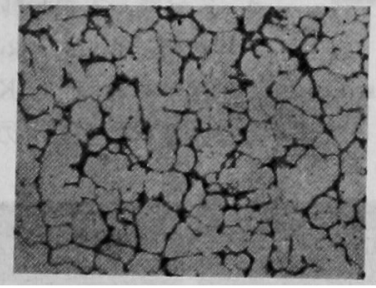

(b) SKD6I $\times 400$
Photo. 9. Microstructures of SKD11 and SKD61 splats. (Nital etch) $(3 / 5)$
以上の観察結果においてとくに注目すべきは, SKD61 において炭化物の網目が鋳造材には存在しないにかかわ らず，スプラットおよび局部急冷凝固層には存在するこ とである.そこで SKD61 のスプラットを $890^{\circ} \mathrm{C} \times 5$ hr FG の条件で焼なましし，さらに一部を $1000^{\circ} \mathrm{C} \times$ $25 \mathrm{~min}, \mathrm{OQ}$ の条件で焼入れしたところ，Photo. 14 に 示すように鋳造材と同じく粒状の炭化物が均一に分们し た組織となつた. Photo. 14 には焼入組織のみ示したが 焼なましによつてすでにこのような組織に変化してい た.

\section{$3.2 \mathrm{X}$ 線回折}

\section{$3 \cdot 2 \cdot 1$ 高速度鋼}

SKH9 噴霧粉を $\mathbf{H C l}$ 水溶液にて溶解して得た残查を X線回折した. Table 7 はその結果であつて $d=3 \cdot 70$, 1.85 の弱い未知の回折線のほかは $\mathrm{Fe}_{3} \mathrm{O}_{4}, \mathrm{M}_{2} \mathrm{C}, \mathrm{MC}$ の回折線によく一致し, $\mathbf{M}_{6} \mathrm{C}$ の存在を示す回折線は認 められない.

噴霧粉そのものをX線回折すると $\alpha, \gamma$ の回折線 のほかに Table 7 中の $\mathrm{M}_{2} \mathrm{C}$ の $d=2 \cdot 53,2 \cdot 31$, $2 \cdot 22, \mathrm{MC}$ の $d=2 \cdot 08, \mathrm{M}_{2} \mathrm{C}$ の 1.48 または $\mathrm{MC}$ の 1.47 に相当すると考えられる回折線が得られ, やはり $\mathrm{M}_{6} \mathrm{C}$ の存在は認められなかつた. したがつ て凝固のままの噴霧粉は $\alpha, \gamma, \mathrm{M}_{2} \mathrm{C}$ および $\mathrm{Fe}_{3} \mathrm{O}$ から構成されていると結論される. 粉末粒度とこれ らの量比の関係を回折線強度からおよそ判定すると つぎのとおりである. $\mathrm{Fe}_{3} \mathrm{O}_{4}$ は大きな粉末に多くて

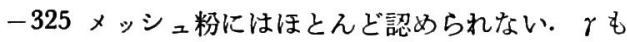

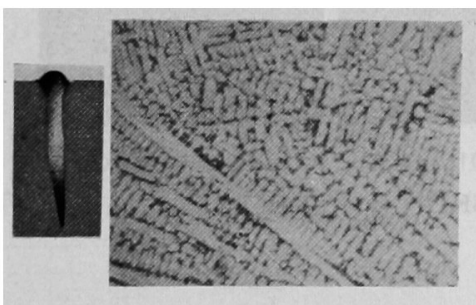

(a) $150 \mathrm{kV}, 25 \mathrm{~mA}, 3250 \mathrm{~mm} / \mathrm{min}$

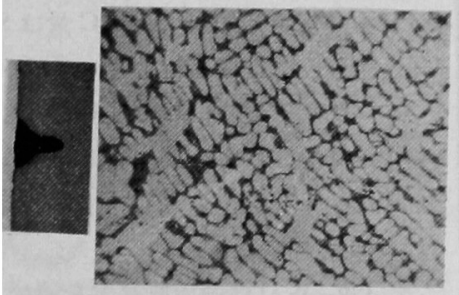

(b) $90 \mathrm{kV}, 4 \mathrm{~mA}, 1000 \mathrm{~mm} / \mathrm{min}$

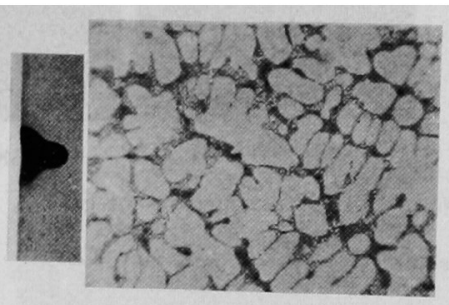

(c) $90 \mathrm{kV}, 4 \mathrm{~mA}, 500 \mathrm{~mm} / \mathrm{min}$

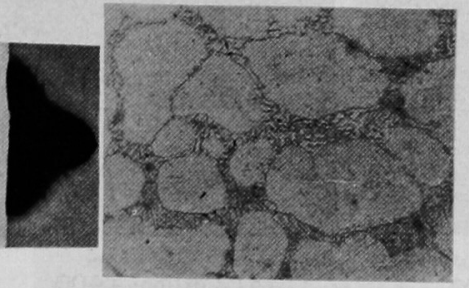

(d) $70 \mathrm{kV}, 8 \mathrm{~mA}, 50 \mathrm{~mm} / \mathrm{min}$

Photo. 10. Microstructures of SKD1 beads made by electron beam melting. $($ Nital etch, Microstructure $\times 1000$, Cross section $\times 4)(3 / 5)$ 


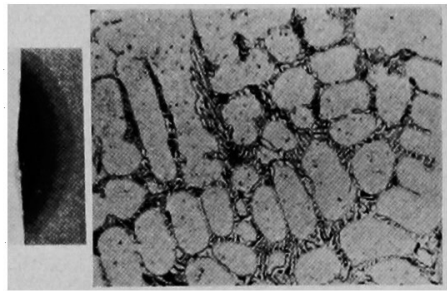

(a) $70 \mathrm{~A}, 120 \mathrm{~mm} / \mathrm{min}$

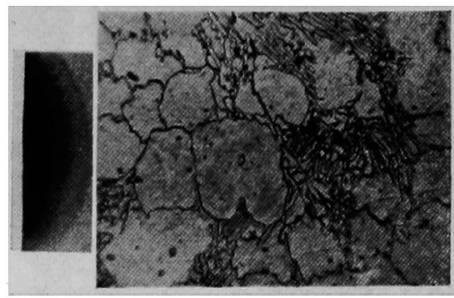

(b) $80 \mathrm{~A}, 80 \mathrm{~mm} / \mathrm{min}$

Photo. 11. Microstructures of SKD1 bead made by Transfer Plasma melting. $($ Nital etch, Microstructure $\times 1000$, Cross section $\times 4)(3 / 5)$

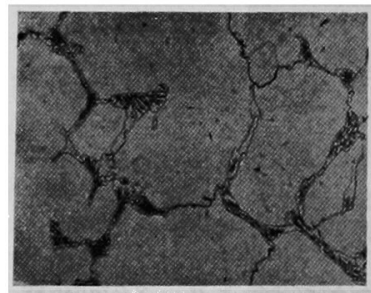

(a) SKDII $\times 400$

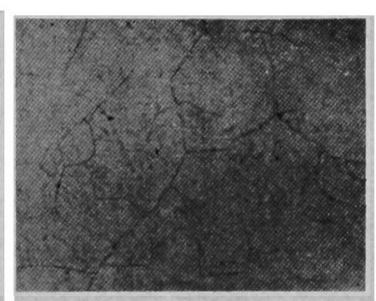

(b) SKD $61 \times 400$
大きな粉末に多いが大きな差ではない. $\mathrm{M}_{2} \mathrm{C}$ は粒 度の大きい粉末に多いが，MC は粉末が小さいほど 多く，20〜100 メッシュ粉にはごくわずかしか認め られなかつた。 また $\alpha$ の回折線は粉末が大きくな るほど拡がり，150メッシュより大きい粉末では $\alpha$ (110) の回折線が $d=2 \cdot 04 \mathrm{~A}^{\circ}$ のほかに $d=2 \cdot 055$ $\mathrm{A}^{\circ}$ に分離して現われた。

Fig. 4 および Fig. 5 は高周波溶解炬で溶解し Photo. 12. Microstructures of SKD11 and SKD6l castings. た溶湯から作つた SKH9, SKH54のスプラットお (Nital etch) $(3 / 5)$ よび鋳造材についての回折チャートである.スプラ

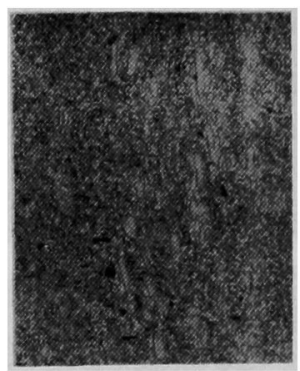

(a) SKDI $\times 400$

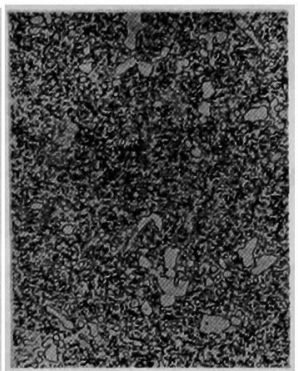

(b) SKDII $\times 400$

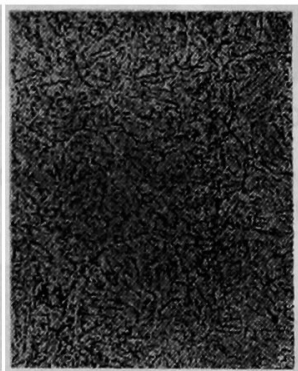

(c) SKD6I $\times 400$

Photo. 13. Microstructures of SKDl, SKD1l and SKD61 forged bars. (Nital etch) $(3 / 5)$

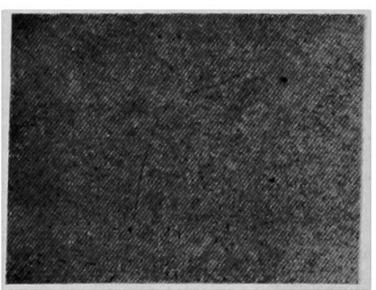

(a) Splat $\times 1000$

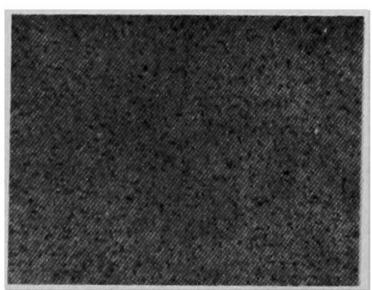

(b) Casting $\times 400$
Photo. 14. Microstructures of SKD61 splat and casting after $1000^{\circ} \mathrm{C} \times 25 \mathrm{~min}$ oil quenching.

(Nital etch) $(3 / 5)$
ットおよび鋳造材中の炭化物も噴霧粉の炭化物と同 じく $\mathrm{M}_{2} \mathrm{C}$ と $\mathrm{MC} て ゙ ， \mathrm{MC}$ 量はSKH9 より SKH54 に多い. $r$ は鋳造材よりもスプラットに多い. また スプラットの $\alpha(110)$ 回折線が二つに分離するこ とはなかつたが，鋳造材の $\alpha(110)$ に比べて大きく 拡がつており，大きなひずみが存在していると考え られる。

Fig. 6 は浮遊溶解装置を用いて作つた高速度鋼 SKH9, SKH54，SKH2 および SKH9 のV量を 1\%（6-5-4-1 鋼）あるいは 0\% (6-5-4-0 鋼）に 減らした鋼のスプラットの X 線回折結果である. 
Table 7. $\mathrm{X}$-ray diffraction line spacings and intensities of the residues extracted from SKH 9 atomized powders.

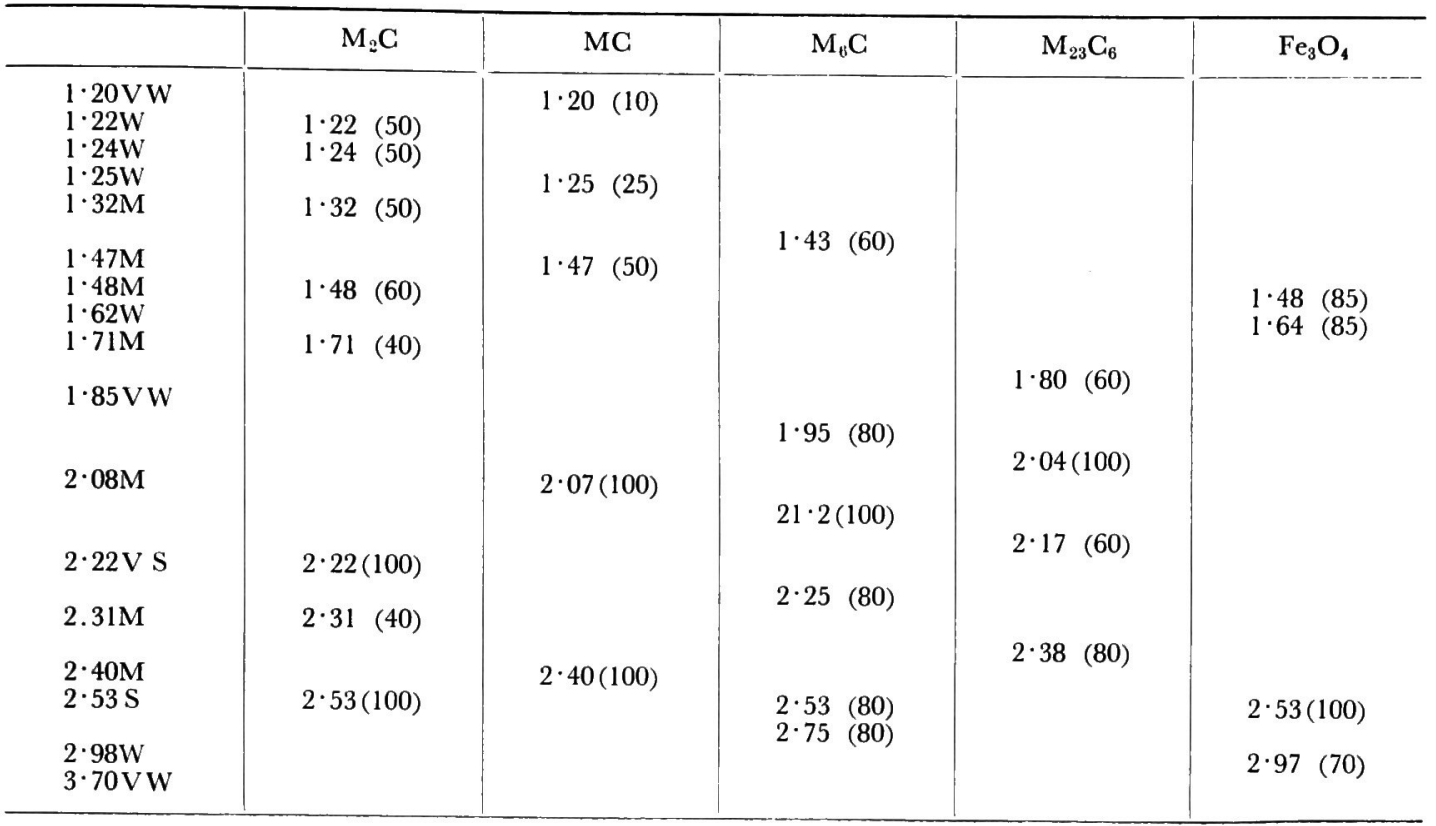

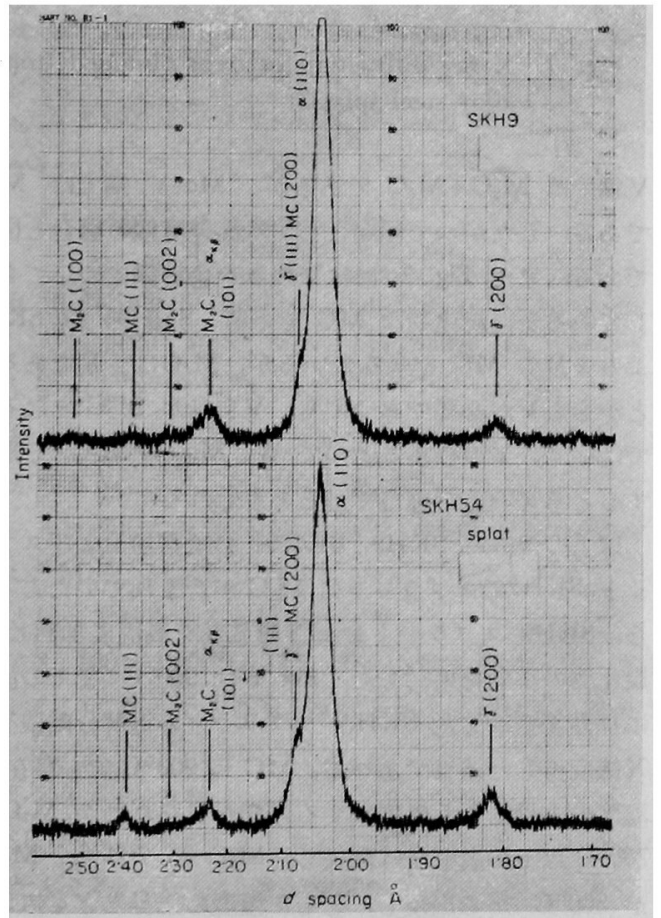

Fig. 4. Charts of X-ray diffraction obtained from SKH9 and SKH54 splats.

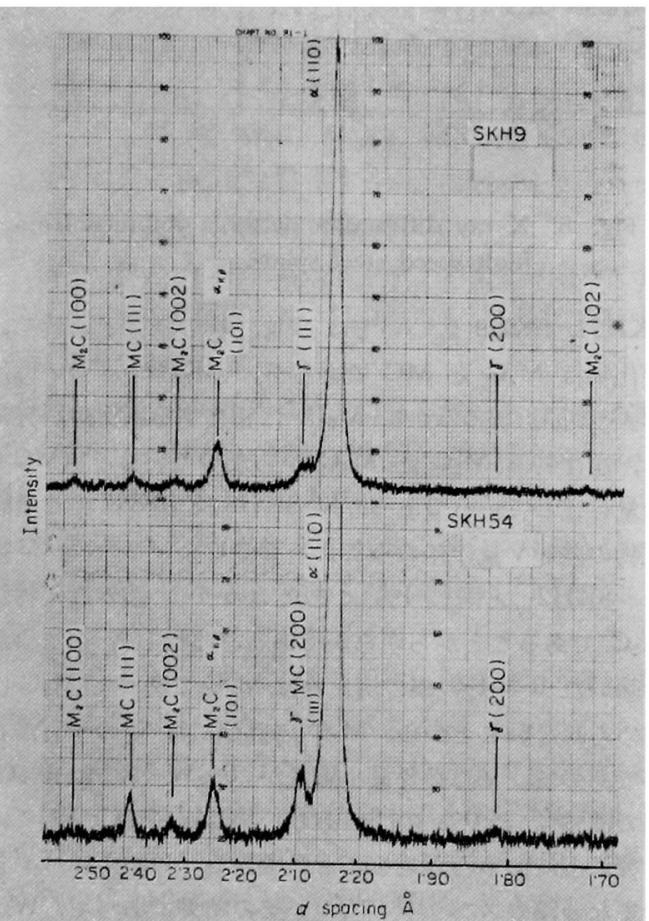

rig. 5. Charts of X-ray diffraction obtained from SKH9 and SKH54 castings. 

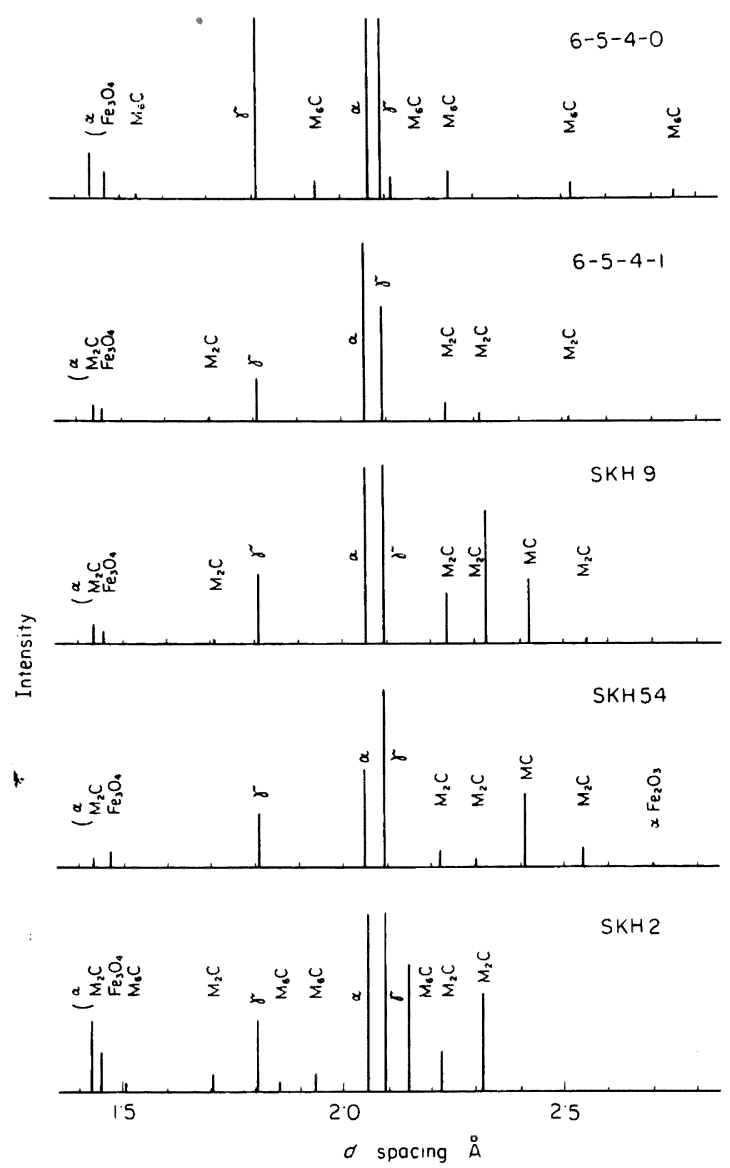

Fig. 6. X-ray diffraction patterns obtained from high speed steel splats.

SKH54, SKH9 については Fig. 4 の結果と一致し, 炭化物は $\mathrm{M}_{2} \mathrm{C}$ と $\mathrm{MC}$ であるが， $\mathrm{SKH} 2$ については $\mathrm{M}_{2} \mathrm{C}$ の回折線のほかに $\mathrm{M}_{6} \mathrm{C}$ に相当する回折線が存在 し，炭化物は $\mathrm{M}_{2} \mathrm{C}$ と $\mathrm{M}_{6} \mathrm{C}$ からなつている. (MCも 少量存在しているであろう). SKH9 と SKH2 のこの炭 化物の差がV量の差のみによるものでないことは， V 量 を SKH2 と同じ $1 \%$ にした 6-5-4-1 鋼の炭化物が $\mathrm{M}_{2} \mathrm{C}$ であることから明らかである. しかし V をまつた く除いた 6-5-4-0 鋼の炭化物は $\mathrm{M}_{6} \mathrm{C}$ であつて $\mathrm{M}_{2} \mathrm{C}$ は 認められないことから， $\mathrm{M}_{2} \mathrm{C}$ の晶出には Vの含有が必 要であつて, Vの必要最小限量が 6\%W-5\% Mo-4\% Cr 鋼では $1 \%$ と $0 \%$ の間にあり，18\%W-4\% Cr 鋼では 1\%以上にあると考えることができる. Fig. 7 は Crを 含まない鋼のスプラットについての結果であつて, Wか Mo を単独に含む鋼の炭化物は $\mathrm{M}_{6} \mathrm{C}$ であり，これにV が $1 \%$ 添加 (W, Mo 量も半減しているが) された W-
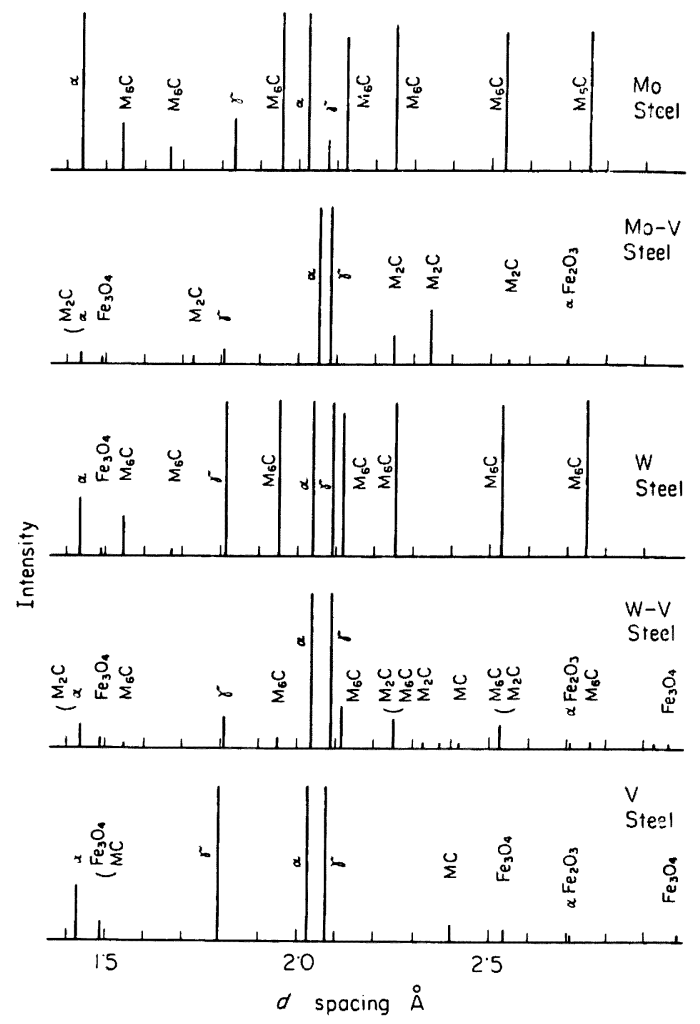

Fig. 7. X-ray diffraction patterns obtained from alloy steel splats.

$\mathrm{V}$ 鋼では $\mathrm{M}_{2} \mathrm{C}+\mathrm{M}_{6} \mathrm{C}$ であるが， $\mathrm{Mo}-\mathrm{V}$ 鋼では $\mathrm{M}_{2} \mathrm{C}$ である.したがつて傾向としては高速度鋼の場合と同じ である.また Fig. 7 にはVのみを含む鋼についても示 してあるが，炭化物は MC である. SKH54 は SKH9 より多量の $\mathrm{MC}$ を含えでいるが， $\mathrm{M}_{2} \mathrm{C}$ は少量であるこ とからも Vが必要であつても， V自身が $\mathrm{M}_{2} \mathrm{C}$ となるの ではなく, Vの存在によつて W, Mo が $\mathrm{M}_{2} \mathrm{C}$ を形成 すると考えるのが妥当であると思われる.

以上のように SKH9, SKH54 の噴霧粉およびスプラ ット, $\mathrm{SKH} 2$ 2スプラットに $\mathrm{M}_{2} \mathrm{C}$ が含まれていたことか ら, SKH9 スプラットおよび櫴蓩粉を高温に加熱して, 炭化物の挙動を検討した. Fig. 8 は $900^{\circ} \mathrm{C}$ までの温度 に加熱後空冷した SKH 9 スプラットの電解分離残査を

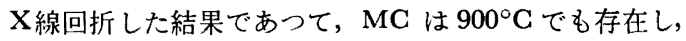
温度の上昇とともに增加する傾向が見られたが, $\mathrm{M}_{2} \mathrm{C}$ は $750^{\circ} \mathrm{C}$ 以上の温度では消失し, $\mathrm{M}_{6} \mathrm{C}$ が $700^{\circ} \mathrm{C}, \mathrm{M}_{28} \mathrm{C}_{6}$ が $800^{\circ} \mathrm{C}$ から出現し, ともに温度の上昇とともに増加 している. また $\mathrm{M}_{7} \mathrm{C}_{3}$ も $700^{\circ} \mathrm{C}$ のみに見られる.この 結果から凝固のままのSKH9スプラットに存在した $\mathrm{M}_{2} \mathrm{C}$ 
Table 8. X-ray diffraction lines spacings and intensities of the residues extracted from as solidified and annealed SKDI6 splats.

\begin{tabular}{|c|c|c|c|c|c|c|c|c|}
\hline As solidified & $\begin{array}{l}950^{\circ} \mathrm{G} \times \\
2 \mathrm{hr} \text { F.c. }\end{array}$ & $\alpha$ & $\gamma$ & $\mathrm{M}_{2} \mathrm{G}$ & $\mathrm{MC}$ & $\mathrm{M}_{6} \mathrm{C}$ & $\mathrm{M}_{7} \mathrm{C}_{3}$ & $\mathrm{M}_{23} \mathrm{C}_{6}$ \\
\hline $\begin{array}{l}1 \cdot 47 \mathrm{~W} \\
1 \cdot 70 \mathrm{VW} \\
1 \cdot 81 \mathrm{~W} \\
2 \cdot 03 \mathrm{~W} \\
2 \cdot 07 \mathrm{M} \\
2 \cdot 09 \mathrm{Mi} \\
\\
2 \cdot 21 \mathrm{~W} \\
\\
2 \cdot 39 \mathrm{M} \\
2 \cdot 53 \mathrm{VW}\end{array}$ & $\begin{array}{l}1 \cdot 44 \mathrm{VW} \\
1 \cdot 47 \mathrm{~W} \\
1 \cdot 76 \mathrm{M} \\
1 \cdot 81 \mathrm{M} \\
1 \cdot 85 \mathrm{~W} \\
1 \cdot 95 \mathrm{~W} \\
2 \cdot 03 \mathrm{M} \\
2 \cdot 05 \mathrm{~S} \\
2 \cdot 08 \mathrm{M} \\
2 \cdot 11 \mathrm{~S} \\
2 \cdot 17 \mathrm{VW} \\
2 \cdot 21 \mathrm{VW} \\
2 \cdot 25 \mathrm{~W} \\
2 \cdot 30 \mathrm{M} \\
2 \cdot 40 \mathrm{M} \\
2 \cdot 52 \mathrm{VW} \\
2 \cdot 75 \mathrm{VW}\end{array}$ & $2 \cdot 03(100)$ & $1 \cdot 80 \quad(80)$ & $\begin{array}{l}2 \cdot 22(100) \\
2 \cdot 31 \quad(40) \\
2 \cdot 53(50)\end{array}$ & $2 \cdot 07(100)$ & $\begin{array}{l}1 \cdot 43 \quad(60) \\
\\
\\
1 \cdot 95 \quad(80) \\
\\
2 \cdot 12(100) \\
2 \cdot 25 \quad(80) \\
2 \cdot 53 \quad(80) \\
2 \cdot 75 \quad(80)\end{array}$ & $\begin{array}{ll}1 \cdot 71 & (60) \\
1 \cdot 75 & (70) \\
1.81 & (70) \\
1.84 & (60) \\
1.96 & (60)\end{array}$ & $\begin{array}{l}1 \cdot 80(60) \\
2 \cdot 04(100)\end{array}$ \\
\hline
\end{tabular}

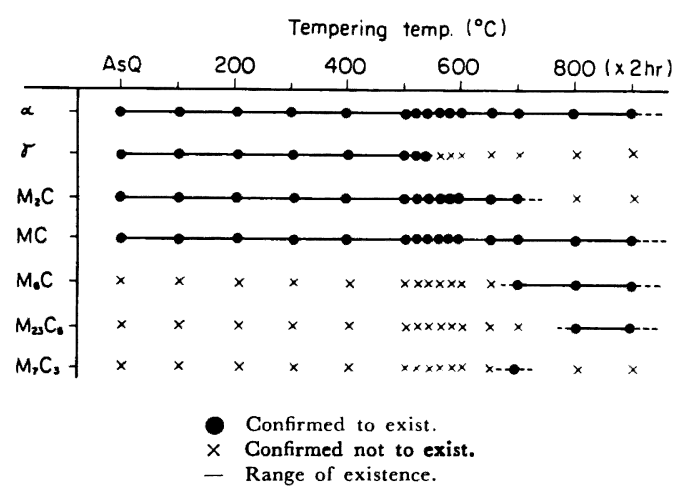

Fig. 8. Kind of carbides identified in SKH9 high speed steel after tempering at various temperatures.

は熱的に不安定であつて, 高温に加熱すると消失するこ とが明らかである. $900^{\circ} \mathrm{C} 2 \mathrm{hr}$ 加熱した SKH54 スプ ラットについてX線回折した結果， $\mathrm{M}_{2} \mathrm{C}$ は認められず, $\mathrm{MC}, \mathrm{M}_{6} \mathrm{C}, \mathrm{M}_{23} \mathrm{C}_{6}$ が存在したので, SKH9 スプラッ トと同じ挙動をすると推定される.

また $100 \sim 1000^{\circ} \mathrm{C} 0.5 \sim 2 \mathrm{hr}$ 加熱した $\mathrm{SKH}^{n}$ 噴霧 粉について調べたところ，スプラットとほほ同じ結果で あつた・

\section{$3 \cdot 2 \cdot 2$ ダイス鋼}

SKD 61 のスプラットおよび鋳造材についてX線回折 したところ, 凝固のままの組織中に存在する炭化物はと もに $\mathrm{M}_{2} \mathrm{C}, \mathrm{MC}$ である. 凝固のままおよび $950^{\circ} \mathrm{C} 2$ $\mathrm{hr}$ 加熱後のスプラットの電解分離残査についての回折
線を Table 8 に示したが, 両者の間には明らかに差が あり,

（1） $950^{\circ} \mathrm{C}$ 加熱後のスプラットから得た残査の回折 線は, $\mathrm{M}_{6} \mathrm{C}, \mathrm{M}_{23} \mathrm{C}_{6}, \mathrm{M}_{7} \mathrm{C}_{3}$ によく一致しているのに対 して, 凝固のままのスプラットから得た残査の回折線は $\mathrm{M}_{6} \mathrm{C}$ にほとんど一致せず, $\mathrm{M}_{23} \mathrm{C}_{6}$ には 2 本一致するが 最強線ではなく， $\mathrm{M}_{7} \mathrm{C}_{3}$ には 1 本一致するが最強線では ない. したがつて $\mathrm{M}_{6} \mathrm{C}, \mathrm{M}_{23} \mathrm{C}_{6}, \mathrm{M}_{7} \mathrm{C}_{3}$ は $950^{\circ} \mathrm{C}$ 加熱 したスプラット中には存在するが，凝固のままのスプラ ット中には存在しないと判断される.

(2) $\mathrm{M}_{2} \mathrm{C}$ の回折線は 5 本中 4 本まで凝固のままの スプラット中に認められ, 強度的にも $\mathrm{M}_{2} \mathrm{C}$ と判断する のが妥当である.

(3) MCの回折線は両者に見られることから，凝固 のままでは $\mathrm{M}_{2} \mathrm{C}, \mathrm{MC}, 950^{\circ} \mathrm{C}$ 加熱後では $\mathrm{M}_{6} \mathrm{C}$, $\mathrm{M}_{23} \mathrm{C}_{6}, \mathrm{MC}$ が存在すると判断したのである.

凝固の亡まの鋳造材には炭化物のほかに 見られたが，スプラットには $\gamma$ は認められなかつた。ま たスプラット中の $\alpha$ の回折線は拡がつていた.

上述のように，凝固の亡まの炭化物は $\mathrm{M}_{2} \mathrm{C}$ と $\mathrm{MC}$ ， $950^{\circ} \mathrm{C}$ 加熱後は $\mathrm{M}_{6} \mathrm{C}, \mathrm{M}_{28} \mathrm{C}_{6}$ と $\mathrm{MC}$ であつた。 した がつて高速度鋼の場合と同じように加熱による変化をし らべた. 結果は Fig. 9 のとおりである. $\mathrm{M}_{2} \mathrm{C}$ は 750 ${ }^{\circ} \mathrm{C}$ 以上の温度では見られず, $\mathrm{M}_{6} \mathrm{C}$ が $750^{\circ} \mathrm{C}, \mathrm{M}_{23} \mathrm{C}_{6}$ が $900^{\circ} \mathrm{C}$ から存在した。 また $\mathrm{M}_{7} \mathrm{C}_{3}$ \& $750^{\circ} \mathrm{C}$ に存任 するようである。

SKD11 ではスプラット，鋳造材ともに $\alpha, \gamma$ およ 


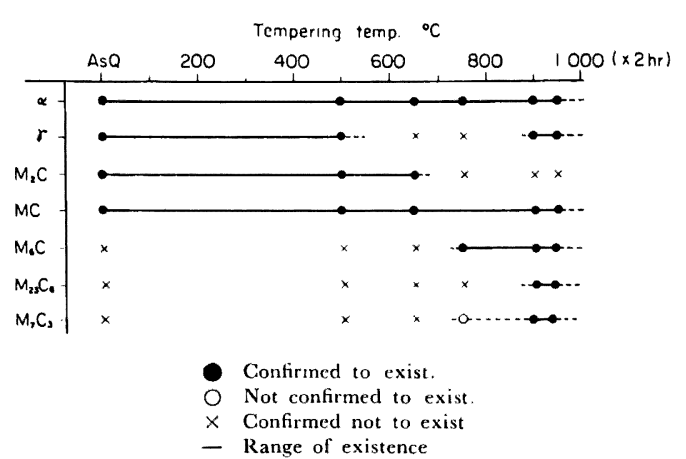

Fig. 9. Kind of carbides identified in SKD61 hot work die steel after tempering at various temperatures.

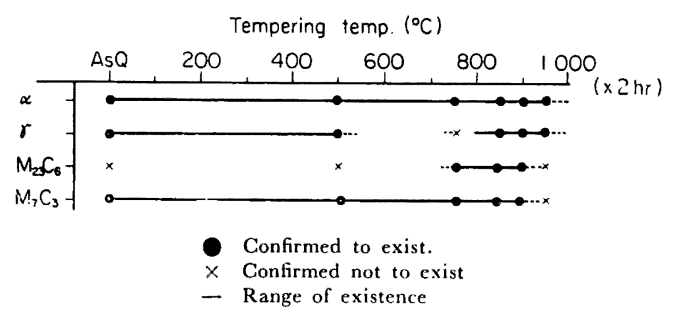

Fig. 10. Kind of carbides identified in SKDll cold work die steel after tempering at various temperatures.

び $\mathrm{M}_{7} \mathrm{C}_{3}$ が存传した. スプラットの $\alpha$ の回折線はやはり 拡がつていた. Fig. 10 は SKD61 と同じように加熱に よる変化を調べた結坚であるが， $\mathrm{M}_{23} \mathrm{C}_{6}$ が $750^{\circ} \mathrm{C}$ から 出現した。

\section{4. 考察}

以上の実験結果から急冷㠜固工具鋼は一般的な冷却速 度で㠜固した工具鋼に比べて，炭化物が微細であるのみ ならず凝固組織にもいろいろ異なつた点が認められる.

したがつてある種の工具鋼を急冷すると徐冷の場合と異 なつた凝固過程をとることが明らかである. また急冷凝 固に関して注目すべき点は高速度鋼やSKD61 には $\mathrm{M}_{2} \mathrm{C}$ が晶出することである. したがつてこの 2 点について以 下若干の考察を行なうことにする.

\section{1 急冷凝固工具鋼の凝固過程}

\section{$4 \cdot 1 \cdot 1$ 高速度鋼}

まず顕微鏡観察，X線回折，X線マイクロアナライザ 一分析，硬さ測定の結果を総合して凝固のままの組織を 構成する各相が何であるかを考える.㗂霧粉, スプラット および局部急冷凝固層に共通して存在する相は，網目を 形成する相, これに囲まれた基質および非網状相である.
網目を形成する相：X線マイクロアナライザーによる 判定結果から, W, Mo, V, Cr, C に富えでおり, X線回 折では $\mathrm{M}_{2} \mathrm{C}$ および MC (SKH9, SKH54) あるいはこ のほかに $\mathrm{M}_{6} \mathrm{C}$ (SKH2) が検出されていることから， $\mathrm{M}_{2} \mathrm{C} ， \mathrm{MC}$ あるいは $\mathrm{M}_{6} \mathrm{C}$ 型炭化物である．炭化物にし てはマイクロアナライザーによる值が低いのはビーム径 に対して炭化物の大きさが十分でないからであろう.

網状相に冉まれた基質：焼もどしによつて腐食され Hv 800 以上の硬さを持つている（ただし網状炭化物を 含えだ硬さである）ことからマルテンサイトであるが， X線回折から $\gamma$ も相当量含まれている.

非網状相：焼もどし後でもマルテンサイトのように腐 食されず，硬さも Hv 500 と低いこと，網状相に先行し て晶出したと推定されることおよび状態図からフェライ 卜と判断される. その中に存在する微粒は W, Mo, Cr, $\mathrm{V}$ の少ないおそらく $\mathrm{Fe}$ と $\mathrm{C}$ を主とするものと考えら れる.K. KUo は 18-4-1 型高速度鋼を固相線以上の温 度に加熱した後油冷した組織に存在する $\delta$ 相の中に Photo. 1 と同じように見られる微粒を $\mathrm{M}_{6} \mathrm{C}$ 炭化物と考 えている(2)が，噴霧粉のフェライト中の微粒は $\mathrm{M}_{6} \mathrm{C}$ で ない可能性が強い. 厉お前述の粒度の大きい顂霧粉で $\alpha$ (110) が $d=2.04 \mathrm{~A}^{\circ}$ と $d=2.055 \mathrm{~A}^{\circ}$ の二つに分離して いた原因は基質のマルテンサイトのほかに $\delta$ フェライト が存在するためでないかと考える.

以上の結果から急冷凝固高速度鋼の凝固組織は $\delta-7$ ェライト，炭化物，マルテンサイトおよびオーステナィ

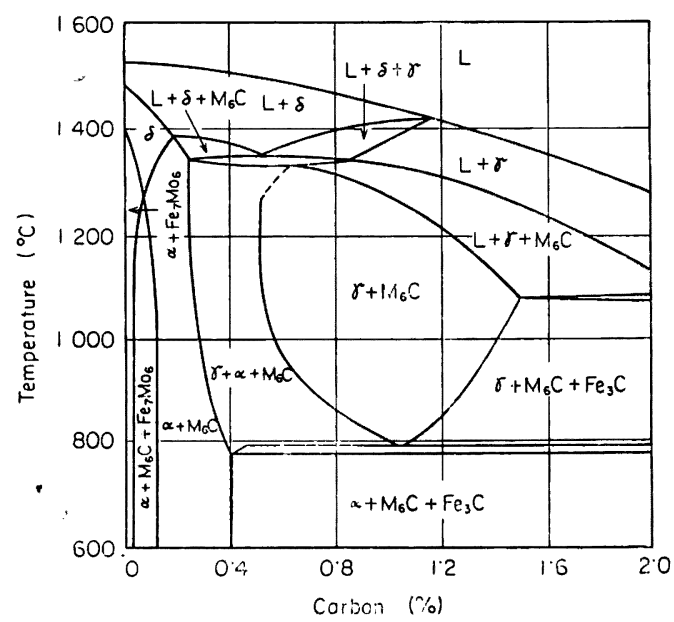

Fig. 11. Constitutional diagram for high speed steel. Binary section through $\mathrm{Fe}: \mathrm{W}$ : $\mathrm{Cr}$ : C system at 18\%W, 4\% Cr as published by Murakami and Hatta ${ }^{18}$ ) and modified by Kuo and GoldschmidT ${ }^{14}$ ). 
トから形成されていると結諭されるが，噴筇粉にはこの ほかに粉末表面を稪つた $\mathrm{Fe}_{3} \mathrm{O}_{4}$ が存在する. また $\delta$ ーフ ェライトは噴簿粉以外にはわずかしか存在しない.

Fig. 11 は村上，八田 ${ }^{13)}$ にる $18 \mathrm{~W}-4 \mathrm{Cr}$ での $\mathrm{Fe}-$ W-Cr-C 系切断状態図を $K . \mathrm{KuO}^{14)}$ が修正したもので ある.

本研究に用いた高速度鋼は $18 \mathrm{~W}-4 \mathrm{Cr}-1 \mathrm{~V}$ の SKH2, 6W-5Mo-4Cr で 2V の SKH9 および同じく $4 \mathrm{~V}$ の SKH54 であるが, 組織に対しては $1 \%$ の Mo が $2 \%$ のWに相当するので，(1) $\mathrm{M}_{6} \mathrm{C}$ のほかにVを主体とする $\mathrm{MC}$ および $\mathrm{Cr}$ を主体とする $\mathrm{M}_{23} \mathrm{C}_{6}$ が存在すること， (2) SKH9 および SKH54 の場合固相線が約 $50^{\circ} \mathrm{C}$ 低温 であること ${ }^{15)}$, (3) V の存在の影響を多少考虑する必要 があることを念頭におくだけでこの戍を凝固過程の考察 のよりどころとして用いることができる.

この図で 0.8\% のC量について凝固の過程を考える と,

(1) 融体からの $\delta$ 相の晶出 $M \rightarrow \delta$

(2) 包晶反応による $\gamma$ 相の生成 $M+\delta \rightarrow \gamma$

（3）包共晶反応による $\gamma$ と $\mathrm{M}_{6} \mathrm{C}$ の生成および $\delta$ の 消失 $M+\delta \rightarrow \gamma+\mathrm{M}_{6} \mathrm{C}$

（4）其晶反応による $\gamma$ と $\mathrm{M}_{6} \mathrm{C}$ の生成および融体の 消失 $\mathrm{M} \rightarrow \gamma+\mathrm{M}_{6} \mathrm{C}$

（5）共析反応による $\alpha$ と $\mathrm{M}_{6} \mathrm{C}$ の生成 $\gamma \rightarrow \alpha+\mathrm{M}_{6} \mathrm{C}$

（6）包共析反応による $\alpha$ と $\mathrm{Fe}_{3} \mathrm{C}$ の生成 $\gamma+\mathrm{M}_{6} \mathrm{C} \rightarrow \alpha+\mathrm{Fe}_{3} \mathrm{C}$

の久応が起こり, 室温では $\alpha, \mathrm{Fe}_{3} \mathrm{C}, \mathrm{M}_{6} \mathrm{C}$ からなるは ずである.しかし鋼塊として銶込まれた高速度鋼が㠜固 する場合には（3）の反応が十分に進行しないて

(4) ${ }^{\prime} \quad \delta \rightarrow \mathrm{M}_{6} \mathrm{C}+\gamma$

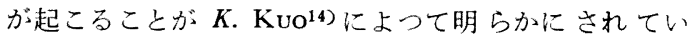
る. また（6）の反応も進行しないので室温ではの変 態したマルテンサイトと $\mathrm{M}_{6} \mathrm{C}$ ，および前述の $\mathrm{MC}$ と $\mathrm{M}_{23} \mathrm{C}_{6}$ からなつている. Photo. 6 の砂型鋳造材の組織 において共晶状炭化物によつて形成された一つの網目の 中に存在する, 内部に点状の模㯆のある白い部分が (4)' の反応によるいわゆる $\delta$ 共析である.

この高速度鋼の㠜固過程に関する知識をもとにして急 冷凝固高速度鋼の㠜固過程について考察してみると

（i） まず（1）の反応は高周波誘導加熱による局部急 冷凝固処理層を除いてはごく部分的にしか行なわれてい ない.なぜなら（1)の反応が著しく進行すれば， $\delta$ ある いは $\delta$ の (4)'の反応による生成相 (共析 $\delta$ ) が多数存

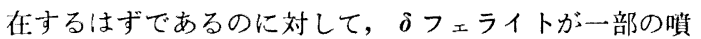

弱粉に局部的に見られるのみで，其析 $\delta$ は見られない. $\delta$ フェライトの存在が粉末内でも片寄つていることか ら，噴㽝汒では個々の粉末の中に泠却条件に大きな差が あると推定される，スプラットでは冷却条件が均一にな りやすいためか，とくに部厚い部分に $\delta$ フェライトが存 在するのみであつた.

(ii) (2)の反応は一部の $\delta$ フェライトについては進 行していると推定される. とくに Photo. 1 c および 1 $\mathrm{d}$ において $\delta$ フェライトの周辺が不規則に入りくんだ形

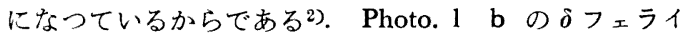
卜は $1 \mathrm{c}$ や $1 \mathrm{~d}$ のそれに比べて輪郭が滑らかであるこ とから，(2)の反応の進行程度は粉末によつて，また粉 末内でも相当に差がありそうである.

(iii) $\delta$ に接した $\gamma+\mathrm{M}_{6} \mathrm{C}$ の包共晶組織が認められ ないことから，(3)の反応はほとえど進行していない。

(iv) $\delta$ の生成が局部的しか認められないので，凝固 は $\delta$ 存在場所を除いては融体からの初晶 $\gamma$ 晶出によつ て行なわれたと推定される，rの晶出した後，残りの融 体は $\mathrm{M} \rightarrow \gamma+$ 炭化物の共晶反态によつて網目状に凝固し ている.

（v）初晶 $\delta$ と融体の間に（2)および（3)の反応が進 行していないので，oの周囲には融体からてが直接晶出 したと考えられる.

（vi）（4）'の反応はほとんど進行せず， $\delta$ が室温を で残留している・ただしうの中には温度の低下とともに 析出が行なわれている.しかし析出物の種類については 不明である.

(vii)（5）と（6）の反応が抑制されて初晶 $\gamma$ および 共晶 $\gamma$ 一部がマルテンサイト变態する.

したがつて高速度鋼の組成を持つ溶融金属が溶融状態 から急冷凝固されると

( I )
(1) $M \rightarrow 0$

$\begin{cases}\text { (2) } & M+\delta \rightarrow \gamma \\ \text { (3) } & M \rightarrow \gamma \\ \text { (4) } & M \rightarrow \gamma+\text { 炭化物 }\end{cases}$

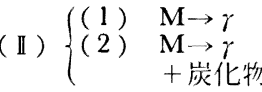

なる二つの反応によつて凝固し，室温安で温度低下与る 間にとの一部はマルテンサイト変態する，そして炭化物 は前述のように $\mathrm{SKH} 2$ を除いては $\mathrm{M}_{6} \mathrm{C}$ でなく $\mathrm{M}_{2} \mathrm{C}$ +MCである.（II）の凝固過程は切断状態㳇において約 $1.5 \%$ 以上の $\mathrm{C}$ 量の融体の凝固過程と一致していて，こ のずれは急冷凝固に起因するものと考元られる.（I）の 凝固過程では切断状態図にしたがつて，瀜体中に $\delta$ フ ライトが晶出する（さらに $\delta$ の部は融体と反応して $\gamma$ となる）のであるが，この反応がごくわずかしか進行し ない間に，この $\delta$ を核として $\delta$ こわりに，あるいは 
には無関係に, 融体中に $\gamma$ が晶出したと判断される。凝 固組織において $\boldsymbol{\delta}$ はつねに共晶で形成された一つの網目 のほぼ中心部に位置していることから， $\boldsymbol{\delta}$ が核となり $\delta$ の表面に $\gamma$ が晶出している可能性が大きい。 $\delta$ はスプラ ットにおいてはとくに厚い部分, 局部急冷凝固層におい ては最終凝固部に見られることから，質霧粉においても 噴霧媒である水との接触あるいは蒸気膜との接触の条件 が，たまたま凝固時の冷却速度を小さくした部分に $\delta$ が 発生したのではないかと推定される．したがつて噴霧の 条件を变えれば $\delta$ の発生量も変化するであるう.

この凝固過程は SKH9，SKH54 および SKH2 に共 通である.SKH54 スプラットの顕微鏡組織は SKH9 のそれと一見相当な差があるようであるが，スプラット であるために $\delta$ てィトが見られないこと，および網 目を形成している炭化物が粒状に近い形であること以外 には差が見られない，炭化物が粒状であるのは一般の高 速度鋼の鋳造組織におかても $\mathrm{M}_{6} \mathrm{C}$ より粒状に近い形で 現われる MC の炭化物中に占める割合が大きいことに よると考えられる.

な求砂型鋳造材は組織から見て (1)，(2)，(4)，(4)' の㠜固過程にしたがつていると推定される.

$4 \cdot 1 \cdot 2$ ダイス鋼について

Fig. 12 は熱間ダイス鋼 SKD61 $\quad(0 \cdot 32 \sim 0 \cdot 42 \% \mathrm{C}$, $4.5 \sim 5.5 \% \mathrm{Cr}, 1 \sim 1.5 \% \mathrm{Mo}, 0.8 \sim 1.2 \% \mathrm{~V}$ ) 中に存在す る量とほぼ等しい $\mathrm{Cr}$ 量である゙5\% $5 \mathrm{Cr}$ における $\mathrm{Fe}-\mathrm{C}-\mathrm{Cr}$ 切断状態図である16). この状態図から SKD61 中の $\mathrm{C}$ 量に相当する $0.35 \%$ の C をもつ溶融金属の㠜固過程は

(1) 融体から $\delta$ 相の晶出 $\mathrm{M} \rightarrow \delta$

（2）包晶反応によるrの生成と $\delta$ の消失

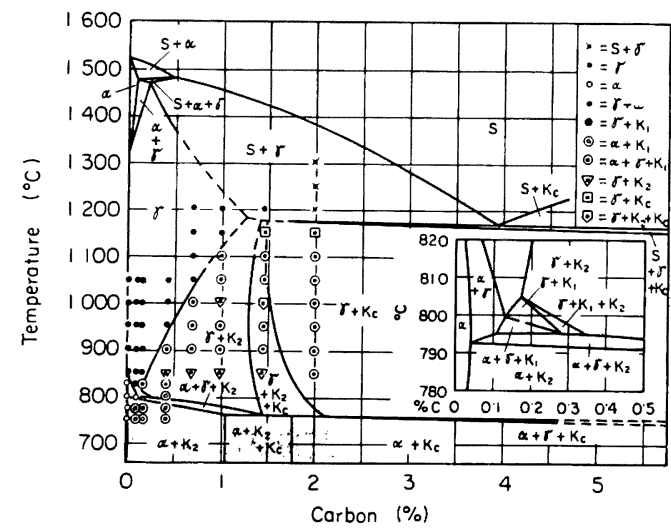

$\left(\mathrm{K} 1=\mathrm{M}_{23} \mathrm{C}_{5} \quad \mathrm{~K} 2=\mathrm{M}_{7} \mathrm{C}_{3} \quad \mathrm{KC}=\mathrm{Fe}_{3} \mathrm{C}\right)$

Fig. 12. Constitutional diagram for $\mathrm{Cr}$ steel after $K$. Bungardt, $E$. Kunze and $E$. Horn' ${ }^{16)}$. Binary section at $5 \% \mathrm{Cr}$.

$$
\mathrm{M}+\delta \rightarrow \gamma
$$

（3） $\gamma$ の晶出による融体の消失 $\mathbf{M} \rightarrow \gamma$

(4) $\gamma$ から $\mathrm{M}_{7} \mathrm{C}_{3}$ の析出 $\gamma \rightarrow \gamma+\mathrm{M}_{7} \mathrm{C}_{3}$

(5) $\gamma$ の共析変態による $\alpha$ と $\mathrm{M}_{7} \mathrm{C}_{3}$ の生成

$$
r \rightarrow \alpha+\mathrm{M}_{7} \mathrm{C}_{3}
$$

であり炭化物の晶出は行なわれない.なお（1）および (2) の反応は (3) に比べて著しく少量である. この切 断状態図において析出する炭化物は $\mathrm{M}_{7} \mathrm{C}_{3}$ であるが, 後述のように SKD61 に存在する 炭化物は $\mathrm{M}_{23} \mathrm{C}_{6}+$ $\mathrm{M}_{6} \mathrm{C}+\mathrm{MC}$ である. これは SKD61 中には $\mathrm{Cr}$ の他に Mo および V が存在するためである. したがつてSKD 61 に関しては上述の $(4)$ および(5)の炭化物は $\mathrm{M}_{7} \mathrm{C}_{3}$ で はなく $\mathrm{M}_{23} \mathrm{C}_{6}+\mathrm{M}_{6} \mathrm{C}+\mathrm{MC}$ と修正して考えるべきであ る.

顕微鏡組織の観察結果では砂型鋳造材は一相からなる 基質の中に粒状の炭化物が析出した形であつて，上述の 凝固過程を経たものと推定される.これに対してスプラ ットおよび局部急冷凝固処理層は初晶粒の間隙を共晶組 織が網目状に埋めた形であつて，明らかにたとえば砂型 鋳造材の上うな徐冷凝固上は異なつた過程を経て凝固し たと推定される.

その過程は

(1) 融体加らの晶出，M $\rightarrow r$

（2）共晶反応に上る融体の消失 $\mathrm{M} \rightarrow \gamma+$ 炭化物

SKD61 に含有されている $1 \%$ の V および $1.4 \% の$ Mo の影響については，その含有量が比較的小さいこと から SKD61 スプラットおよび局部急冷湜固層において

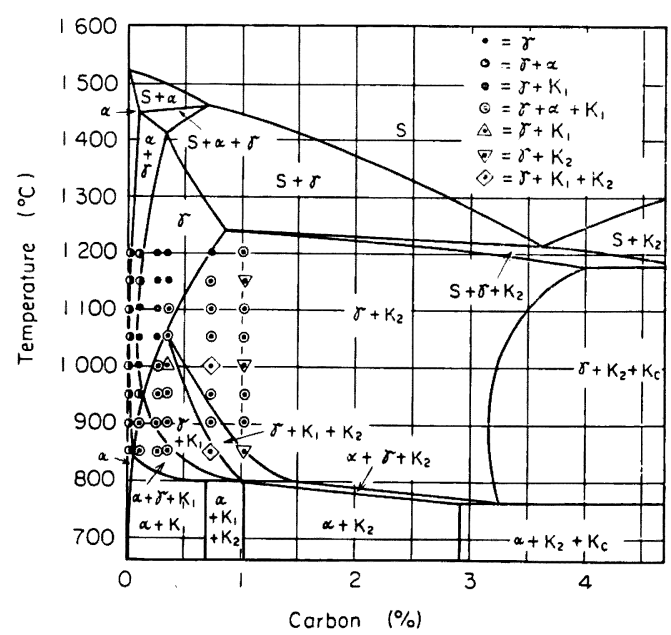

Fig. 13. Constitutional diagram for $\mathrm{Cr}$ steel after $K$. Bungardt, E. Kunze and $E$. Horn ${ }^{16)}$. Binary section at $13 \% \mathrm{Cr}$. 
共晶が現われたのは V および Mo の影響ではなく, 急 冷によつて高速度鋼の場合と同じく, 凝固過程が高 $\mathrm{C}$ 側 (1·25\%以上)にずれたためであると判断される.

Fig. 13 は冷間ダイス SKD11 中に存在するのとほほ 等しい $\mathrm{Cr}$ 量である $13 \% \mathrm{Cr}$ における $\mathrm{Fe}-\mathrm{C}-\mathrm{Cr}$ 系の切 断状態図16)である. この状態図から SKD11 (1·4〜1.6 $\% \mathrm{C}, 11 \sim 13 \% \mathrm{Cr}, 0.2 \sim 0.5 \% \mathrm{~V}, 0.8 \sim 12 \% \mathrm{Mo})$ 中の $\mathrm{C}$ 量に相当する $1 \cdot 5 \% \mathrm{C}$ および $\mathrm{SKDI} \quad(1 \cdot 8 \sim 2 \cdot 4 \% \mathrm{C}$, $12 \sim 15 \% \mathrm{Cr}$ ) 中の $\mathrm{C}$ 量に相当する $2 \cdot 1 \% \mathrm{C}$ の溶融金属 の凝固過程は

(1) 融体からの $r$ 相の晶出 $\mathrm{M} \rightarrow \gamma$

(2) 共晶反応による融体の消失 $\mathrm{M} \rightarrow \gamma+\mathrm{M}_{7} \mathrm{C}_{3}$

(3) 共析反応による $\alpha$ と $\mathrm{M}_{7} \mathrm{C}_{3}$ の生成

$$
\gamma \rightarrow \alpha+\mathrm{M}_{7} \mathrm{C}_{3}
$$

である・

顕微鏡組織の観察結果では，SKD11 の砂型鋳造材お よびスプラット, SKD1 の砂型鋳造材および局部急冷凝 固層は初晶粒の間隙を共晶組織が網目状に埋めた形に凝 固した組織であると考えられ，SKD1やSKD11 では 急冷凝固の場合でも状態図にしたがつて凝固している.

以上の結果から冷間ダイス鋼では急冷凝固（ここでは スプラットまたは噴霧粉程度の冷却速度での凝固と考え る)しても, 徐冷㠜固（ここでは砂型鋳造材よりも小さ (冷却速度での凝固と考点る）の場合と凝固過程に差が 見られないのに対して, 熱間ダイス鋼 SKD61 や高速度 鋼では急冷凝固によつて徐冷凝固とは異なつた過程で凝 固し, 凝固速度の影響は鋼組成によつて差のあることが 明らかになつた。

\section{2 急冷凝固工具鋼の炭化物}

\section{$4 \cdot 2 \cdot 1$ 高速度鋼}

高速度鋼中の炭化物についてはこれまで多くの研究が ありながら，そのほとえどが焼なまし，焼入あるいは焼
もどし状態についてのものであつて, 凝固のままの材料 についてはあまり報告が見られないが，炭化物腐食およ び組成分析から $\mathrm{M}_{6} \mathrm{C}$ と $\mathrm{MC}$ であるとした報告がある

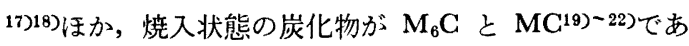
ること， $18 \mathrm{~W}-4 \mathrm{Cr}$ 切断状態図に示されている炭化物が $\mathrm{M}_{6} \mathrm{C}$ である23)ことから一般に $\mathrm{M}_{6} \mathrm{C}$ と $\mathrm{MC}$ であると考 えられている.これに対して本研究の結果によれば SKH9 および SKH54 では急冷凝固材はもとより砂型 鋳造材においてすら検出された炭化物は， $\mathrm{M}_{2} \mathrm{C}$ と $\mathrm{MC}$ であつて $\mathrm{M}_{6} \mathrm{C}$ を検出することができなかつた。 また $\mathrm{SKH} 2$ では $\mathrm{M}_{6} \mathrm{C}$ も存在したが同時に $\mathrm{M}_{2} \mathrm{G}$ も認められ た.

$\mathrm{M}_{2} \mathrm{C}$ 炭化物は後述のように高速度鋼においては焼も どし時の炭化物反応の一段階にのみ認められていた ものであるが最近 $G$. STEVEN らは C 量が $0.86 〜 1.37$ $\%$ ， N 量が 0.01〜0.120\%の範囲の 9\%Mo-2\%W-4\% $\mathrm{Cr}-2 \% \mathrm{~V}$ 型, $8 \% \mathrm{~W}-5 \% \mathrm{Mo}-4 \% \mathrm{Cr}-2 \% \mathrm{~V}-12 \% \mathrm{Co}$ およ び 5\%W-8\%Mo-4\%Cr-2\%V-12\%Co 型高速度鋼の鍛 造材（鍛造後 $870^{\circ} \mathrm{C}$ に焼なまし）の炭化物をX線回折 およびマイクロアナライザーでしらベた結果，Nが少な く $\mathrm{C}$ が高い鋼には Fig. 14 (a)（b)に示すように $\mathrm{M}_{2} \mathrm{C}$ が存在することを見い出した ${ }^{24)}$ (凝固のままの炭化物に ついてはしらべていないが，錢造一焼なまし後に $\mathrm{M}_{2} \mathrm{C}$ であれば凝固のままでも $\mathrm{M}_{2} \mathrm{C}$ であろう)。この研究に よればこれまで高速度鋼に $\mathrm{M}_{2} \mathrm{C}$ が見られなかつたのは Nの存在のためであるが, Table 1 に示したC量および $\mathrm{N}$ 量では噴霧粉は Fig. 14 の $\mathrm{M}_{6} \mathrm{C}$ 存在範囲にあり, $\mathrm{M}_{2} \mathrm{C}$ の存在は説明できない.

また最近，仁平25)らは 900〜 $1300^{\circ} \mathrm{C}$ で焼入したSKH 2, SKH9 および $2 \% \mathrm{~W}-9 \% \mathrm{Mo}-1 \% \mathrm{~V}$ 高速度鋼の炭化 物をX線回折し，2\%W-9\% Mo- $1 \% \mathrm{~V}$ 高速度鋼中に存 在する炭化物は $1100^{\circ} \mathrm{C}$ 焼入では $\mathrm{M}_{6} \mathrm{C}$ であるが, 1300
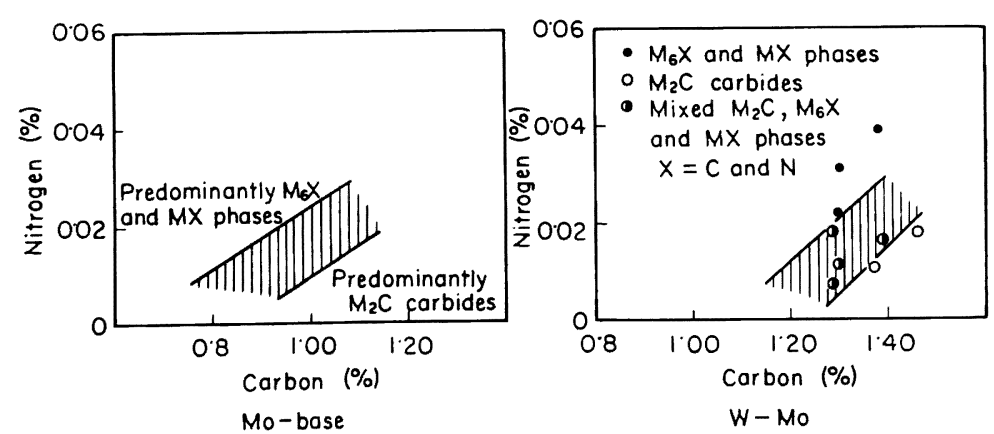

Fig. 14. Effect of carbon and nitrogen contents on the morphology of residual (primary) carbides in high speed steel. (after $G$. StEven, et al. ${ }^{24)}$ ) 
${ }^{\circ} \mathrm{C}$ では $\mathrm{M}_{6} \mathrm{C}$ がわずかで大部分が $\mathrm{M}_{2} \mathrm{C}$ であることを 認めている. $1300^{\circ} \mathrm{C}$ では相当量の液相が発生している はず15)であつて, 本研究の結果と相通ずるところがあ る. SKH9, SKH2 には $\mathrm{M}_{2} \mathrm{C}$ は認められていない.

なお $G$. STEVEN ${ }^{24)}$ の研究では 9\%Mo- $2 \% \mathrm{~W}-4 \% \mathrm{Cr}$ $2 \% \mathrm{~V}$ 鋼中の $\mathrm{M}_{2} \mathrm{C}$ は $(\mathrm{Fe} 0.33, \mathrm{Mo} 0.33, \mathrm{~V} 0.2$, C $0 \cdot 1, W 0 \cdot 04)_{2} \mathrm{C}$ なる式で示される組成を持つてい て Mo, V, Cr それぞれを相当量含えでいるので, SKH 9 のW量が多いことを考虑すれば， C， Mo, Cr， V お よびWに富んだ網状相を $\mathrm{M}_{2} \mathrm{C}$ としたこれまでの判断は 誤りでないであろう.

このように唄雾粉やスプラットのように急冷凝固高速 度鋼に晶出する炭化物は $\mathrm{M}_{6} \mathrm{C}$ でなく $\mathrm{M}_{2} \mathrm{C}$ であるとい う興味ある現象が見い出されたのであるが，鋼塊のよう な徐冷凝固した高速度鋼に晶出する炭化物が $\mathrm{M}_{6} \mathrm{C}$ であ るとのこれまでの一般的な概念がもし正しければ（凝固 のままの鋼塊中の炭化物をX線回折でしらべたデーター は見当らないので， $\mathrm{M}_{6} \mathrm{C}$ であることには多少疑問があ ると考える)，それより大きい速度で凝固すれば $\mathrm{M}_{2} \mathrm{C}$ が 晶出し, それ以下の速度ならば $\mathrm{M}_{6} \mathrm{C}$ が晶出する臨界の 冷却速废が存在するはずである. 砂型鏞造材の炭化物も $\mathrm{M}_{2} \mathrm{C}$ であることからこの臨界速度は砂型鋳造材の冷却 速度よりは小さいことは確かであるが，これについても 今後の検討が必要である.

$\mathrm{M}_{2} \mathrm{C}$ が晶出するための組成上の条件については $6 \%$ W-5\%Mo-4\% Cr では 0〜1\%, 18\%W-4\%Cr では 1 \%以上，12.5\%Mo では 0〜1\%，15\%W では 0〜1\% の間のある值のVが必要であることを $3 \cdot 2 \cdot 1$ 項に述べ たが，SKD61 の炭化物も $\mathrm{M}_{2} \mathrm{C}$ であつたことから，1.3 $\% \mathrm{Mo}-5 \% \mathrm{Cr}$ の場合でも $\mathrm{M}_{2} \mathrm{C}$ 形成に必要な $\mathrm{V}$ の最小 限量は 0 〜 $\%$ の間の值である.

急冷凝固における特異現象の一つとして平衡状態でも 沽相領域からの急冷によつても得られない新しい相の出 現が観察され，その一例として Fe-C 系で “epsilon”な る h.c.p の新しい準安定相が報告されている26).この epsilon は $\varepsilon$ 炭化物とは異なるもので高在下でのみ存 在する $\mathrm{Fe}$ の h.c.p と同じものではないかと考えられ ている. $\mathrm{M}_{2} \mathrm{C}$ の存在がこれと類似の機構によるもので あるか否かは明らかでなく今後の検討が必要であろう.

つぎ焼入された高速度鋼を焼もどしするとつぎのよ うな炭化物反応が起きることが確かめられている21)27).

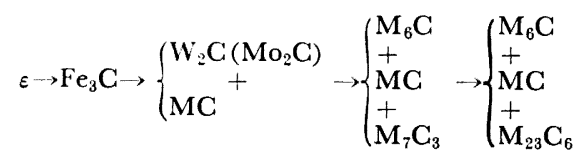
$200^{\circ} \mathrm{C} \quad 650^{\circ} \mathrm{C}$
この反応において $\mathrm{M}_{2} \mathrm{C}$ に相当する $\mathrm{W}_{2} \mathrm{C}$ (W 高速度 鋼）および $\mathrm{Mo}_{2} \mathrm{C}$ (Mo 高速度鋼）は焼もどし時間によ つても多少変わるが $650^{\circ} \mathrm{C}$ の焼もどしで出現し， $750^{\circ}$ $\mathrm{C}$ 以上の焼もどしで消失している．このことから急冷凝 固した高速度鋼を焼もどしすると，存在していた $\mathrm{M}_{2} \mathrm{C}$ も消失することが推定されるのであるが，Fig. 18 から 予想どおり凝固時に形成された $\mathrm{M}_{2} \mathrm{C}$ も烧もどし時に形 成される $\mathrm{M}_{2} \mathrm{C}$ と同じく不安定な炭化物であつて

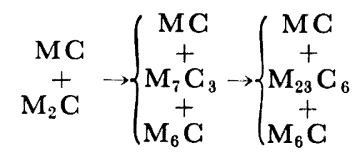

なる炭化物反応が行なわれることが明らかになつた・炭 化物が微細で正確な電解分離が困難なために定量を行な わなかつたので, 反応の前後における $\mathrm{MC}$ 量の変化が 明らかでなく，(1） $\mathrm{M}_{2} \mathrm{C}$ の一部は $\mathrm{MG}$ に変化したの か, (2) $\mathrm{M}_{2} \mathrm{C}$ のみが $\mathrm{M}_{6} \mathrm{C}$ と $\mathrm{M}_{23} \mathrm{C}_{6}$ に変化し, $\mathrm{MC}$ に変化がなかつたのか，(3) あるいは $\mathrm{MC}$ の一部も $\mathrm{M}_{6} \mathrm{C}, \mathrm{M}_{28} \mathrm{C}_{6}$ の形成のために消費されたかに関しては 断定の資料がない，ただし焼入時に残留した炭化物の関 与していない基質鋼を用いて測定して明らかにされた炭 化物反応27において， MCが $650^{\circ} \mathrm{C}$ においてはじめて 出現していることから, 急冷凝固材においても基質から のMCの析出は起こつていたと考えるのが自然と考えら れる. また凝固のままの急冷凝固材が低い温度で焼もど しされた場合には，焼入された鍛造材におけると同じよ

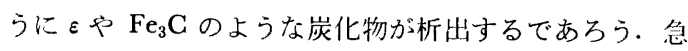
冷㠜固材の基質の中の $\mathrm{C}$ 量が鍛造材のそれに比べてとく に少ないとは考えられず，また Fe 原子の動きやすさが 急冷㠜固材中でとくに劣ると考えられる理由が見当たら ないからである.

\section{$4 \cdot 2 \cdot 2$ 熱間ダイス鋼}

熱間ダイス鋼 SKD61 についても高速度鋼の場合と同 じように，凝固のままの炭化物の同定に関する報告が見 られないが，焼なまし状態では $\mathrm{M}_{23} \mathrm{C}_{6}+\mathrm{M}_{6} \mathrm{C}+\mathrm{MC}$ で あることが䜑められている28). したがつて一般には実用 鋼塊の凝固のままの状態の炭化物はこの 3 種類からなる と考えられているのであろう. (Fe-Cr-C 状態図16)では $\mathrm{Cr}_{7} \mathrm{C}_{3}$ である). 少なくとも $\mathrm{M}_{2} \mathrm{C}$ の出現は予想されて いなかつたと考えられる. したがつて凝固時に晶出する 炭化物が $\mathrm{M}_{2} \mathrm{G}$ と $\mathrm{MC}$ であることは高速度鋼の場合と 同じように興味ある現象である.SKD61 と高速度鋼で は焼なまし状態でも, 急冷凝固状態でも存在する炭化物 種類が等しいのである.つぎに示すように SKD11 の炭 化物が焼なまし状態で $\mathrm{M}_{23} \mathrm{C}_{6}+\mathrm{M}_{6} \mathrm{C}+\mathrm{MG}$ でなく, 急 
冷凝固状態で $\mathbf{M}_{2} \mathbf{C}+\mathbf{M C}$ でないことを考え合わせると 前述のように急冷凝固状態における $\mathrm{M}_{2} \mathrm{C}$ の晶出は $\mathrm{M}_{6} \mathrm{C}$ の形成元素である $\mathrm{W}$ または Mo が一定量以上の V と 共存してはじめて行なわれるのである.

熱間ダイス鋼 SKD61 の焼もどし時の炭化物反応につ いては

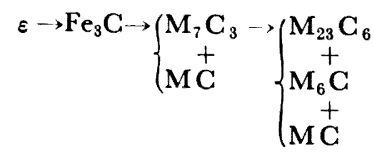

$200^{\circ} \mathrm{C} \quad 600^{\circ} \mathrm{C} \quad 800^{\circ} \mathrm{C}$

なる反応が起きるここが確められている20)。この式には $\mathrm{M}_{2} \mathrm{C}$ は示されていないが，少量ながら Mo の入つてい る以上 $\mathrm{M}_{2} \mathrm{C}$ も出現すると考えるのが妥当であろう ${ }^{27}$.

したがつて凝固のままの状態で存在した炭化物 $\mathrm{M}_{2} \mathrm{C}$ および MC もやはり焼もどしによつて高速度鋼の場合 と同じような炭化物反応を起こすことが予測されるので あるが，Fig. 9 から高涑度鋼の場合と同じ

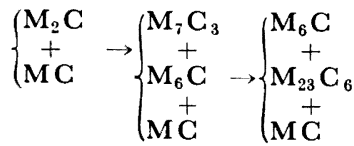

なる反応が行なわれることが確められた。ただし高速度 銅の場合と異なつて $\mathrm{M}_{7} \mathrm{C}_{3}$ が $\mathrm{M}_{23} \mathrm{C}_{6}$ に変化する反応に は長時間を要すると考えられる.

$4 \cdot 2 \cdot 3$ 冷間ダイス鋼

これについても㠜固のままの状態の炭化物の同定に関 する報告が見られないが，焼なましされた SKD11 鍛造 材では， $\mathrm{M}_{23} \mathrm{C}_{6}{ }^{29)}$ ， あるいは $\mathrm{M}_{23} \mathrm{C}_{6}+\mathrm{M}_{7} \mathrm{C}_{3}{ }^{30)}$ であり

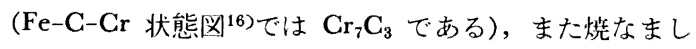
の進行とともに $\mathrm{M}_{7} \mathrm{C}_{3} \rightarrow \mathrm{M}_{23} \mathrm{C}_{6}$ に変化することが確め られている20). したがつて徐冷によつて凝固したままの 組織中に存在する炭化物は $\mathrm{M}_{23} \mathrm{C}_{6}$ か $\mathrm{M}_{7} \mathrm{C}_{3}$ あるいはこ れの混合であると推定される. これに刘して砂型鋳造材 およびスブラットは $\mathrm{M}_{7} \mathrm{C}_{3}$ であるので徐泠によつて $\mathbf{M}_{23} \mathrm{C}_{6}$ が生成されることが事実の場合にのみ急冷凝固 の影響として $\mathrm{M}_{23} \mathrm{C}_{6}$ のかわりに $\mathrm{M}_{7} \mathrm{C}_{3}$ が生成されるこ とになる。

玲問ダイス鋼 SKD11 の焼もどし時における炭化物反 応はつぎのとおりである29).

$$
\begin{gathered}
\varepsilon \rightarrow \mathrm{Fe}_{3} \mathrm{C}->\mathrm{M}_{7} \mathrm{C}_{3} \rightarrow \mathrm{M}_{23} \mathrm{C}_{6} \\
200^{\circ} \mathrm{C} \quad 600^{\circ} \mathrm{C} \quad 750^{\circ} \mathrm{C}
\end{gathered}
$$

したがつて急泠凝固材を焼もどしすると, 存在した $\mathrm{M}_{7} \mathrm{C}_{3}$ が $\mathrm{M}_{23} \mathrm{C}_{6}$ に変化することが推定されるが， Fig. 10 から推定どおり

$$
\mathrm{M}_{7} \mathrm{C}_{3} \rightarrow \mathrm{M}_{23} \mathrm{C}_{6}
$$

の反応は起きることが確められた.

また SKDI 鍛造材の炭化物は燃なむし状態では $\mathrm{M}_{7} \mathrm{C}_{3}{ }^{29)}$ であるので，凝固のままでも $\mathrm{M}_{7} \mathrm{C}_{3}$ であろう。

したがつて炭化物, 種類に閥しては急冷凝固の影響は見 られない.

\section{5. 結論}

急冷凝固した高凍度鋼 SKH2, SKH9, SKH54, 冷間 ダイス鋼 SKD1，SKD11，熱間ダイス鋼 SKD61 およ び W，Mo，Cr，V などを含む合金鋼について顕微鏡 観察，X線回折，EPMA 分析などを行ない，急冷凝固 したこれらの鋼の凝固過程，炭化物反応などを明らかに した，得られた結諭はつきのとおりである。

（1）急冷凝固した高速度鋼および冷間ダイス鋼中の 炭化物は，市服の鍛造材中の炭化物に比べて著しく微細 である。

（2）高速度鋼や熱間ダイス鋼を急冷凝固させると徐 冷㠜固の場合と異なつた凝固過程をとる。

（3）高速度鋼の場 合には初晶 $\gamma$ の晶出と, $\gamma+$ 炭化 物共晶によつて凝固が行なわれる. 比較的冷却速度の小

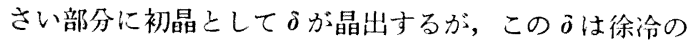
場合の初晶 $\delta$ のように包晶反応および包共晶反応によつ て消失することなく，ほとんよ゙そのまま室温まで存在す る. $\delta$ はとくに噴雾粉に多く認められた。

（4）SKD61 の場合には徐冷㠜固と異なり $r+$ 炭化 物共晶によつて凝固が行なわれる.

（5）SKH9，SKH54 が急汾㠜活したときに晶出す る炭化物は $\mathrm{M}_{6} \mathrm{C}$ と $\mathrm{MC}$ でなく $\mathrm{M}_{2} \mathrm{C}$ とC である。 $\mathrm{SKH} 2$ の場合には $\mathrm{M}_{6} \mathrm{C}$ と $\mathrm{M}_{2} \mathrm{C}$ である.

(6) SKD61 に晶出する炭化物を $\mathrm{M}_{6} \mathrm{C}+\mathrm{M}_{23} \mathrm{C}_{6}+$ $\mathrm{MC}$ でなく $\mathrm{M}_{2} \mathrm{C}$ と $\mathrm{MC}$ である.

（7）晶出した $\mathrm{M}_{2} \mathrm{C}$ は焼もどし時の炭化物反応で形 成される $\mathrm{M}_{2} \mathrm{C}$ と同じく $700^{\circ} \mathrm{C}$ を越す温度での加熱に よつて消失する.

（8）鍛造材上に電子・ビームによつて作られた局部急

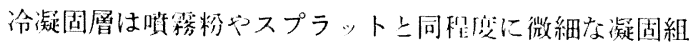
織を持つている.

（9）W および Mo の炭化物は一定量以上のVが共 存すれ活 $\mathrm{M}_{2} \mathrm{C}, \mathrm{V}$ が仔在しなければ $\mathrm{M}_{6} \mathrm{C}$ 上して晶出 する.

\section{文献}

1) N. B. Schwartz: Iron Age, 206(1970)5, p. 78

2 ) I. Strömblad: International Conferrence on the Science and Technology of Iron and Steel, Tokyo Japan, September 7-11, 1970 Conference Preprints p. 160 
3 ) $A . R$. Johnson ${ }^{-}$and $J . C$. Hamaker: ASM Technical Report G7-201, 1967 National Metal Congress 16-19, Oct. 1967, Cleveland, Ohio

4 ) C. L. Korbin: Iron Age, 200(1967) 23, p. 71

5 ) O.W. Reen: Progress in Powder Metallurgy, $20(1964)$, p. 194

6 ）山口，新保，村山，鈑島：粉体粉末冶金協会 昭和 45 年度秋季大会請演概要

7) P. Duwez: Trans. ASM, 60(1967), p. 607

8 ) P. Predeck, $A . W$. Mullendore, and $N . J$. Grant: Trans. Met. Soc. AIME, 233(1965) p. 1581

$9)$ ).$R$. Harbur, $J . W$. Anderson, and $W . J$. Maraman: Los Alamos Scientific Lab. of the University of California Report No LA-3584 July 1966

10) 小柴: 工具材料 (下) p. 373 [丸善]

11) $A$. $H$. Grobe and $G$. A. Roberts: Trans. ASM, 45(1953), p. 415

12) K. Kuo: JISI, 181 (1955), p. 128

13) 村上, 八田: 鉄と鋼, 21(1935), p. 993

14) $K$. Kuo: JISI, 179(953), p. 223

15) E. Kunze and $F$. Horn: DEW Technische Berichte, 1(1961), p. 6
16) K. Bungardt, E. Kunze, and E. Horn: Arch. Eisenhüttenw., 20(1958), p. 193

17）沢，飛世，渋谷，木村：日特技報，1(1965)，p.7

18) $T$. $K$. Jonec. and T. MukherJee: JISI, 196 (1970) p. 90

19) $T$. Malkiewicz, $Z$. Bojarski, and $J$. Foryst: JISI, 185(1959), p. 25

20) J. P. Gill: Trans. ASM, 24(1936), p. 735

21）佐藤，西沢，村井：鉄と鋼，45(1959)， p. 409

22) 小柴, 木村, 原田: 鉄と鋼, 44(1958), p. 1185

23）村上, 八田：鉄と鋼，21 (1935), p. 993

24) $G$. Steven, $J \cdot J$. Hauser, $T$. $A$. Neumeyer, and $J . M$. Capenes: Trans. ASM Quarterly, 62(1969), p. 180

25）仁平，大友：東京都立工業奖励館報告，第22号 (1970), p. 45

26) R. C. Ruhl, M. Cohen: Acta Met., 15(1967), p. 159

27）佐藤，西沢：金属学会会報，2(1963)，p. 564

28）佐藤，西沢，玉置：鉄と鋼，46(1960), p. 1549

29) 佐藤, 本田, 西沢: 鉄と鋼, 42(1956), p. 1118

30) $W$. Tofaute, $C$. Küttner, and $A$. Büttinghaus: Arch. Eisenhüttenw., 9(1935/36), p. 607 